\title{
Reconstructionand Sub-grouping of Batak Languages
}

\author{
Himpun Panggabean ${ }^{1}$, Robert Sibarani ${ }^{2}$, Dwi Widayati ${ }^{3}$, \\ Namsyah Hot Hasibuan ${ }^{4}$ \\ ${ }^{1}$ Universitas Methodist Indonesia, Medan, Indonesia, ${ }^{2}$ Universitas Sumatera Utara, Medan, \\ Indonesia, ${ }^{3}$ Universitas Sumatera Utara, Medan, Indonesia, ${ }^{4}$ Universitas Sumatera Utara, Medan, Indonesia
}

Abstract:This article contains a report of research into reconstruction and sub-grouping of Batak languages (BLs) composed of Toba language (TL), Simalungun language (SL), Pakpak Dairi language (PDL), Angkola language ( $A L)$, Karo language (KL), and Mandailing language (ML) spoken in North Sumatera, Indonesia.The research problems cover the sound correspondences, proto-phonemes, and sub-grouping of BLs. The data are the utterances of the native speakers of BLsbeing recorded in IPA Kiel transcription and are analysed with comparative method. The analysis shows that sound correspondence sets in BLs are of two types, namely the sets resulted from linear inheritance and the setsfrom sound innovation.Based on the correspondence sets, proto-phonemes are reconstructed and BLs are sub-grouped.The analysis also shows that BLs can be classified into three sub-groups, namely TL-AL-ML, PDL-KL, and SL.

Keywords: Batak languages, sound correspondences, proto-phonemes, reconstruction, sub-grouping.

\section{Introduction}

Languages keep changing. The changes of languages occur regularly and recognizably and can be seen in genetically related languages called sister languages. Schleicher (1871) in McManiset al. (1987:265) proposed the Family Tree Theory assuming that languages change in regular, recognizable ways (the Regularity Hypothesis) and that because of this, similarities between languages are due to genetic relationship between those languages (the Relatedness Hypothesis).

Batak languages (BLs) comprising Toba language (TL), Simalungun language (SL), Pakpak Dairi language (PDL), Angkola language (AL), Karo language (KL), and Mandailing language (ML) spoken in six neighboring areas in North Sumatera, Indonesia are genetically-related languages. Crowley (1992:90) states that languages that have genetic relationships are descended from the same proto-language. BLs are descended from a proto-language $\mathrm{p}(\mathrm{BLs})$, for they are genetically-related and have similarities between them which are regular and recognizable as shown by sound correspondence sets. The correspondence sets are the basis of the reconstruction of proto-phonemesand BLs' sub-grouping.

In the following table, the correspondence sets are shown.

Table 1

\begin{tabular}{|c|c|c|c|c|c|c|}
\hline Glos & TL & SL & PDL & AL & KL & ML \\
\hline bamboo & 'bulu & 'buluh & 'buluh & 'bulu & 'buluh & 'bulu \\
\hline
\end{tabular}

The correspondence sets for bamboo are /b-b-b-b-b-b/, /u-u-u-u-u-u/, /1-1-1-1-1-1/, /u-u-u-u-u-u/, and / $\phi-$ $\mathrm{h}-\mathrm{h}-\phi-\mathrm{h}-\phi /$. Based on the correspondence sets, the proto-phonemes of BLs can be reconstructed. The protophoneme for the first set is $/ * \mathrm{~b} /$, for the second set is $/ * \mathrm{u} /$, for the third set is $/ * 1 /$, for the fourth set is $/ * \mathrm{u} /$, and for the fifth set is $/ * \mathrm{~h} /$.The reason for the reconstruction of $/ * \mathrm{~b} /, / * \mathrm{u} /$, and $/ * \mathrm{l} /$ is the fact that those phonemes are inherited linearly by allof the sister languages, Tl, Sl, PDl, $\mathrm{Al}, \mathrm{Kl}$, and $\mathrm{Ml}$ from the proto-language $\mathrm{p}(\mathrm{BLs})$. The reason for the reconstruction of $/ * \mathrm{~h} /$ as the proto-phoneme of the fifth set is the phenomenon that in languages, $/ \mathrm{h} /$ is commonly lost.

The proto-phoneme /*h/ develops into / $\phi /$ in SL,PDL, and KL undergoes retention in TL, AL, and ML.. By comparing the proto-phoneme and its reflexes, sound change can be formulated. The rule of the sound change in the correspondence set $/ \phi-\mathrm{h}-\mathrm{h}-\phi-\mathrm{h}-\phi /$ is $/ * \mathrm{~h} /$ changes into $/ \phi /$ in TL, AL, and ML at the final position before vowel $(\mathrm{h} \rightarrow \phi / \ldots \#)$.

On the basis of the sound change of BLs, the languages can be sub-grouped into TL-AL-ML and SLPDL-ML. However, when additional data are available, the sub-grouping separates SL from the latter as shown below and places it in a position that does not belong to the former or to the latter. 
Table 2

\begin{tabular}{|c|c|c|c|c|c|c|}
\hline Glos & TL & SL & PDL & AL & KL & ML \\
\hline die & 'mate & 'matei & 'mat $\varepsilon$ & 'mat $\varepsilon$ & 'mat $\varepsilon$ & 'mate \\
\hline
\end{tabular}

In the table, sound correspondence / $\varepsilon$-ei- $-\varepsilon-\varepsilon-\varepsilon-\varepsilon /$ isolates SL from TL-PDL-AL-KL-ML because it is the only language that has /ei/ in the final position. Since SL is isolated, the sub-grouping is TL-AL-ML, PDL$\mathrm{KL}$, and SL. In rigorous data as shown in the following part of the article, such sub-grouping is clear.

In conjuction with what is stated previously, the research questions deal withsound correspondence sets, proto-phonemes, sound changes, and sub-grouping of BLs.

\section{The Method of Research}

Following this is the method of approaching the research questions.

\section{Data Gathering}

The data are gathered using a list of BLs' basic vocabulary. Each of the words in the data gathering instrument matches a word in each of TL, SL, PDL, AL, KL, and ML. The sources of the data are the utterances of the native speakers of each of the languages. Their utterances are recorded in phonetic symbols using IPA Kiel. The data to be analysed are only free-morphemes, meaning that bound morphemes are excluded.

\section{SoundCorrespondence Sets}

The data having been gathered are examined by using comparative method to discover sound correspondence sets, namely the phonemes in BLs that are similar or share retention and those that share innovation.

\section{Reconstruction of Proto-phonemes}

The reconstruction of a proto-phoneme is conducted by looking into every sound in asoundcorrespondence set. The sounds that are similar in comparable sets in all of BLs are the reflexes of a single proto-phoneme similar to them. The reconstruction of phonemes that undergo innovation is based on what sounds have the largest distributions and what sound changes are the most plausible.

\section{Rule of Sound Change}

Following the discovery of proto-phonemes, the rules of sound change from proto-phonemes into their reflexes may be formulated by examining the regularity of the sound changes.

\section{Sub-grouping}

The sub-grouping is conducted by grouping BLs in accordance with shared innovation occurring in BLs. The languages with shared innovation are placed in one group.

\subsection{Linear Sound Correspondence Sets}

\section{Linear Sound Correspondence Sets}

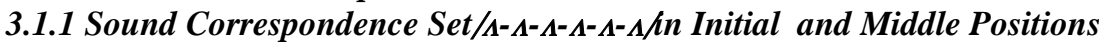

Sound correspondence set $/ \Lambda-\Lambda-\Lambda-\Lambda-\Lambda-\Lambda$ in BLs occurs regularly and recurrently in initial and middle positions as seen below:

Initial Positions

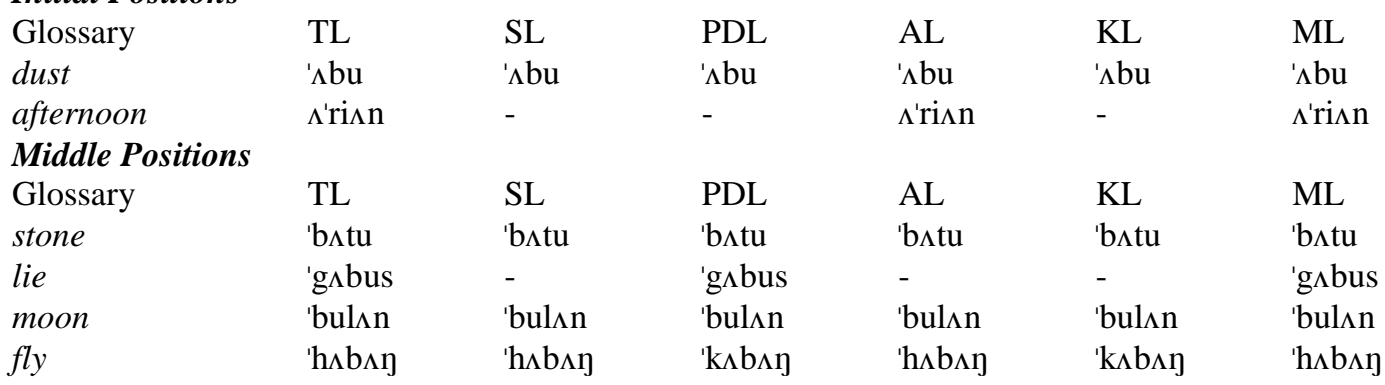

Langacker (1972:334) and Crowley (1992:96) state that the choice of proto-segment to underlie a correspondence is straight forward when its reflex is the same in all daughter languages. In the above data, the sounds in correspondence set $/ \Lambda-\Lambda-\Lambda-\Lambda-\Lambda-\Lambda /$ in initial and middle positions are the same, namely $/ \Lambda /$ in TL, SL, PDL, AL, KL, and ML.In other words, it can be stated that the sounds are linearly inherited from the same sound. On the basis of the fact, the reconstruction of the proto-phoneme is conducted by choosing $/ *_{\Lambda} /$ as the proto-phoneme since its reflex is the same in all six sister languages.

The distributionof $/ \Lambda /$ is as follows:

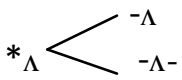




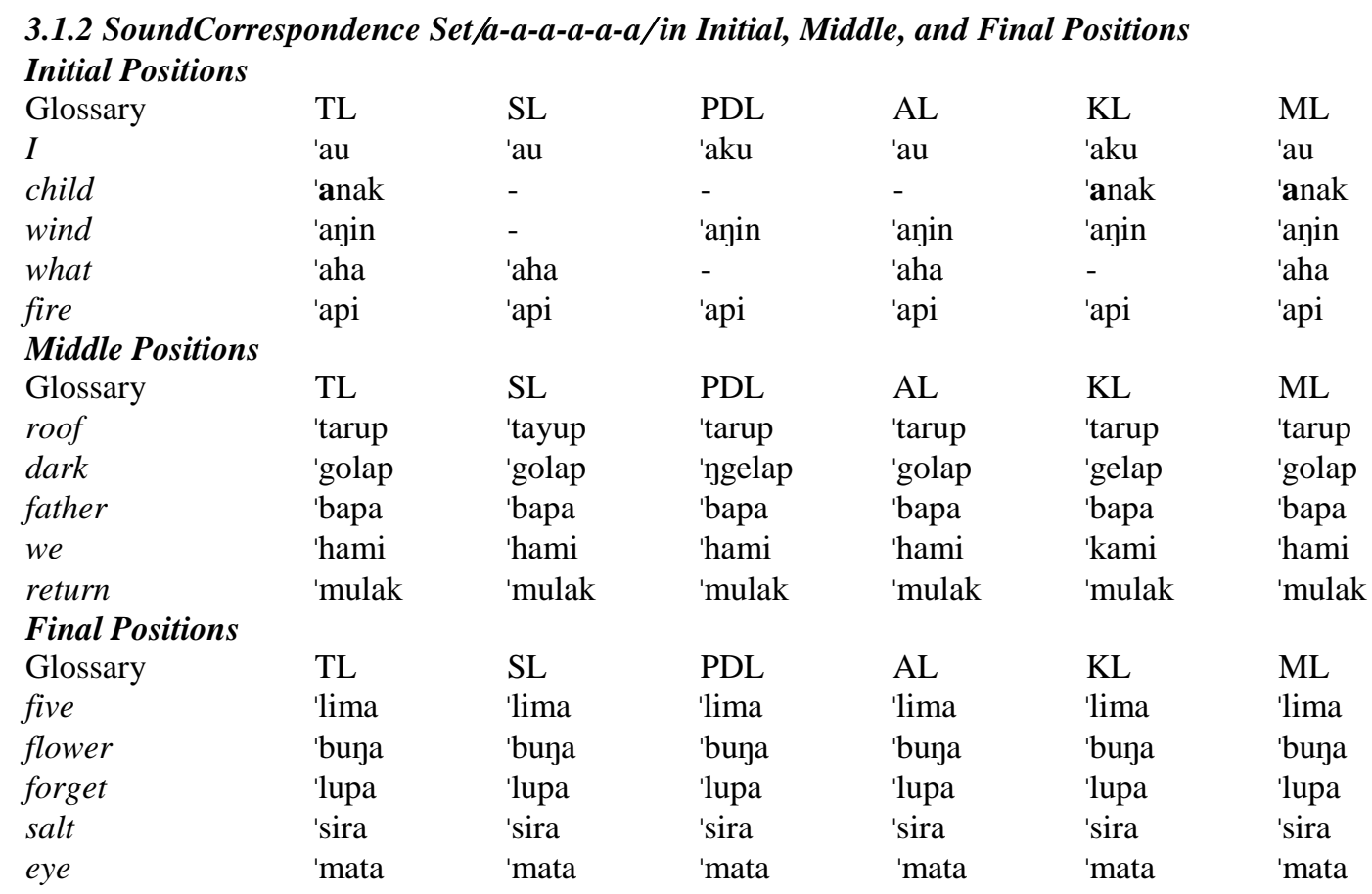

The method of reconstruction applied above is used to reconstruct the proto-phoneme of /a-a-a-a-a-a/. In the above data, the sounds in correspondence set /a-a-a-a-a-a/ in initial, middle, and final positions are the same, namely /a/ in TL, SL, PDL, AL, KL, and ML. In other words, it can be stated that the sounds are linearly inherited from the same sound. On the basis of the fact, the reconstruction of the sound correspondence set is conducted by choosing /*a/ as its proto-phoneme since its reflex is the same in all six sister languages.

The distribution of $/ \mathrm{a} /$ is as follows:

a<smiles>CC(C)C1CCCC1</smiles>

\subsubsection{Sound Correspondence Set /u-u-u-u-u-u/ in Initial, Middle, and Final Positions}

Sound correspondence set /u-u-u-u-u-u/in BLs occurs regularly and recurrently in initial, middle, and final positions as shown below:

\begin{tabular}{|c|c|c|c|c|c|c|}
\hline \multicolumn{7}{|c|}{ Initial Positions } \\
\hline Glossary & TL & SL & PDL & $\mathrm{AL}$ & $\mathrm{KL}$ & ML \\
\hline rain & 'ud $\Lambda \mathrm{n}$ & 'ud $\Lambda \mathrm{n}$ & 'ud $\Lambda \mathrm{n}$ & 'ud $\Lambda \mathrm{n}$ & 'ud $\Lambda \mathrm{n}$ & 'ud $\Lambda \mathrm{n}$ \\
\hline don't & 'unay & 'ulan & 'ulan & 'unay & ulan & 'unan \\
\hline snake & 'ul॰k & 'ulok & - & 'ulok & - & 'ul॰k \\
\hline \multicolumn{7}{|c|}{ Middle Positions } \\
\hline Glossary & TL & SL & PDL & $\mathrm{AL}$ & KL & ML \\
\hline take & 'buet & 'bust & 'buat & 'buat & 'bust & 'buat \\
\hline smoke & 'timus & 'timus & - & 'timus & - & 'timus \\
\hline chicken & 'manuk & - & 'manuk & 'manuk & 'manuk & 'manuk \\
\hline burn & 'tutun & 'tutun & 'tutun & 'tutun & 'tutun & 'tutun \\
\hline bamboo & 'bulu & 'buluh & 'buluh & 'bulu & 'buluh & 'bulu \\
\hline \multicolumn{7}{|c|}{ Final Positions } \\
\hline Glossary & TL & SL & PDL & $\mathrm{AL}$ & KL & ML \\
\hline$I$ & 'au & 'au & 'aku & 'au & 'aku & 'au \\
\hline thosand & 'ribu & 'ribu & 'ribu & 'ribu & 'ribu & 'ribu \\
\hline three & 'tolu & 'tolu & te'lu & 'tolu & te'lu & 'tolu \\
\hline seven & 'pitu & 'pitu & 'pitu & 'pitu & 'pitu & 'pitu \\
\hline
\end{tabular}

The method of reconstruction applied above is used to reconstruct the proto-phoneme of $/ \mathrm{u}-\mathrm{u}-\mathrm{u}-\mathrm{u}-\mathrm{u}-\mathrm{u} / \mathrm{s}$ In the above data, the sounds in correspondence set /u-u-u-u-u-u/ in initial, middle, and final positions are the same, namely /u/ in TL, SL, PDL, AL, KL, and ML. In other words, it can be stated that the sounds are linearly 
inherited from the same sound. On the basis of the fact, the reconstruction of the sound correspondence set is conducted bychoosing $/ * \mathrm{u} /$ as its proto-phoneme since its reflex is the same in all six sister languages.

The distribution of $/ \mathrm{u} /$ is as follows:<smiles>[AlH2]C([AlH2])[AlH2]</smiles>

\subsubsection{Sound Correspondence Set R-i-i-i-i-i//}

Sound correspondence set /i-i-i-i-i-i/ in BLs occurs regularly and recurrently in initial, middle, and final positions as shown below:

\section{Initial Positions}

\begin{tabular}{|c|c|c|c|c|c|c|}
\hline $\begin{array}{l}\text { Glossary } \\
\text { chin }\end{array}$ & $\mathrm{TL}$ & SL & PDL & $\mathrm{AL}$ & $\mathrm{KL}$ & $\begin{array}{l}\text { ML } \\
\text { 'isan }\end{array}$ \\
\hline tooth & $\begin{array}{l}\text { 1san } \\
\text { 'ipon }\end{array}$ & 'ipon & 'isan & $\begin{array}{l}\text { 'isay } \\
\text { 'ipon }\end{array}$ & $\begin{array}{l}\text { 'isan } \\
\text { 'ipen }\end{array}$ & $\begin{array}{l}\text { Isaa } \\
\text { 'ipon }\end{array}$ \\
\hline nose & 'igun & 'igun & 'egun & 'igun & 'igun & 'igun \\
\hline remember ${ }^{\prime}$ & 'inot & 'inat & - & 'inot & 'inet & linot \\
\hline who & 'ise & 'ise & 'ise & 'ise & 'ise & se \\
\hline \multicolumn{7}{|c|}{ Middle Positions } \\
\hline Glossary & TL & SL & PDL & $\mathrm{AL}$ & KL & $\mathrm{L}$ \\
\hline calf & 'bitis & 'bitis & 'bitis & 'bitis & 'bites & is \\
\hline lips & 'bibir & 'bibir & 'bibir & 'bibir & 'biber & \\
\hline wash & 'buri & burih & bu'rih & - & bu'rih & - \\
\hline lick & 'dilıt & 'dilıt & 'ndilat & 'dil $\Lambda \mathrm{t}$ & 'dilıt & \\
\hline cat & 'hutin & 'hutin & - & 'hutin & - & 110 \\
\hline sky & 'lı jit & 'lı jit & 'lapit & 'lanit & 'lanit & \\
\hline \multicolumn{7}{|c|}{ Final Positions } \\
\hline Glossary & TL & SL & PDL & AL & KL & $\mathrm{L}$ \\
\hline day & 'ari & 'ari & 'ari & 'ari & 'wari & - \\
\hline bath & 'idi & 'idi & 'idi & 'idi & 'idi & di \\
\hline sweet & toj'gi & - & ten'gi & ten'gi & - & \\
\hline string & 'tali & 'tali & 'tali & 'tali & 'nali & \\
\hline bone & 'holi & 'holi & & 'holi & - & \\
\hline
\end{tabular}

The method of reconstruction applied above is used to reconstruct the proto-phoneme of /i-i-i-i-i-i/. In the above data, the sounds in correspondence set /i-i-i-i-i-i/ in initial, middle, and final positions are the same, namely /i/ in TL, SL, PDL, AL, KL, and ML. In other words, it can be stated that the sounds are linearly inherited from the same sound. On the basis of the fact, the reconstruction of the sound correspondence set is conducted by choosing $/ * \mathrm{i} /$ as its proto-phoneme since its reflex is the same in all six sister languages.

The distribution of $/ \mathrm{i} /$ is as follows:<smiles></smiles>

\subsubsection{Sound Correspondence Set $\not b-b-b-b-b-b /$ in Initial and MiddlePositions}

Sound correspondence set /b-b-b-b-b-b/ in BLs occurs regularly and recurrently in initial and middle positions as shown below:

\section{Initial Positions}

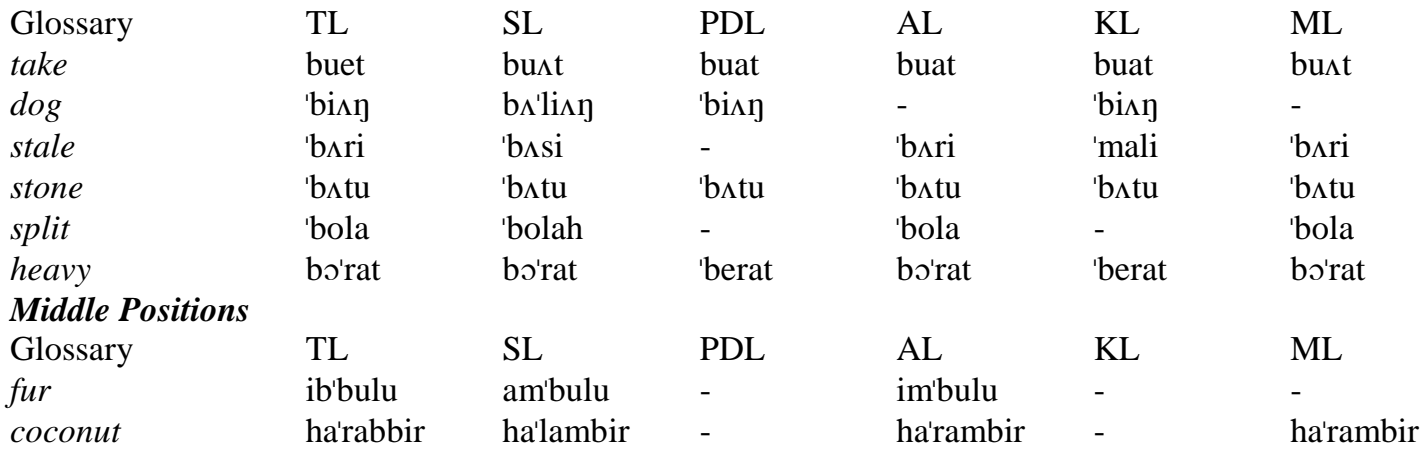


$\begin{array}{llllll}\text { more } & \text { 'lobi } & \text { - } & \text { 'lebih 'lobih }\end{array}$

The method of reconstruction applied above is used to reconstruct the proto-phoneme of /b-b-b-b-b-b/. In the above data, the sounds in correspondence set /b-b-b-b-b-b/ in initial and middle positions are the same, namely /b/ in TL, SL, PDL, AL, KL, and ML. In other words, it can be stated that the sounds are linearly inherited from the same sound. On the basis of the fact, the reconstruction of the sound correspondence set is conducted by choosing $/ * \mathrm{~b} /$ as its proto-phoneme since its reflex is the same in all six sister languages.

The distribution of $/ \mathrm{b} /$ is as follows:

$* \mathrm{~b}$

b-

\subsubsection{Sound Correspondence Set A-t-t-t-t-t/}

Sound correspondence set /t-t-t-t-t-t/ in BLs occurs regularly and recurrently in initial, middle,and final positions as shown below:

\section{Initial Positions}

\begin{tabular}{|c|c|c|c|c|c|c|}
\hline Glossary & $\mathrm{TL}$ & SL & PDL & AL & KL & ML \\
\hline smoke & 'timus & 'timus & - & 'timus & - & 'timus \\
\hline knock & 'tuktuk & 'tuktuk & 'tuktuk & 'tokっk & 'tuktuk & 'tokok \\
\hline sharp & tajom & - & 'tajem & ta'jom & - & tajom \\
\hline string & 'tali & 'tali & 'tali & 'tali & 'nali & 'tali \\
\hline earth & 'tan & 'tanoh & 'tan॰h & 'tan & 'tanoh & 'tan \\
\hline hand & 'tanan & 'tayan & 'tajan & 'tajan & 'tayan & 'tajan \\
\hline \multicolumn{7}{|c|}{ Middle Positions } \\
\hline Glossary & $\mathrm{TL}$ & SL & PDL & $\mathrm{AL}$ & KL & ML \\
\hline calf & 'bitis & 'bitis & 'bitis & 'bitis & 'bites & 'bitis \\
\hline star & 'bittan & 'bittan & 'bintan & 'bintan & 'bintan & 'bintan \\
\hline stupid & 'oto & - & 'moto & 'sto & 'motu & 'oto \\
\hline sap & 'gota & 'gotah & 'getah & 'gota & - & 'gota \\
\hline heart & 'at $\varepsilon$ & 'at $\varepsilon$ & 'at $\varepsilon$ & 'at $\varepsilon$ & 'at $\varepsilon$ & 'at $\varepsilon$ \\
\hline \multicolumn{7}{|c|}{ Final Positions } \\
\hline Glossary & $\mathrm{TL}$ & SL & PDL & $\mathrm{AL}$ & $\mathrm{KL}$ & ML \\
\hline four & 'opat & 'opat & em'pat & 'opat & em'pat & 'opat \\
\hline remember & 'ijot & 'inat & 'enet & 'inot & 'iget & 'ijot \\
\hline lick & 'dilnt & 'dilıt & 'ndilat & 'dilıt & 'dilıt & 'dilnt \\
\hline shock & 'soygot & 'songot & 'seyget & soygot & 'senget & 'songot \\
\hline stingy & ho'lit & ho'lit & ko'lit & ho'lit & - & ho'lit \\
\hline$s k y$ & 'lı jit & 'lı & 'lanit & 'lanit & 'lanit & 'layit \\
\hline
\end{tabular}

The method of reconstruction applied above is used to reconstruct the proto-phoneme of /t-t-t-t-t-t/. In the above data, the sounds in correspondence set /t-t-t-t-t-t/ in initial, middle, and final positions are the same, namely /t/ in TL, SL, PDL, AL, KL, and ML. In other words, it can be stated that the sounds are linearly inherited from the same sound. On the basis of the fact, the reconstruction of the sound correspondence set is conducted by choosing /*t/ as its proto-phoneme since its reflex is the same in all six sister languages.

The distribution of $/ \mathrm{t} /$ is as follows:

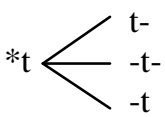

\subsubsection{Sound Correspondence Set $\quad$ j-j-j-j-j-j/}

Sound correspondence set $/ \mathrm{j}-\mathrm{j}-\mathrm{j}-\mathrm{j}-\mathrm{j}-\mathrm{j} /$ in BLs occurs regularly and recurrently in initial and middle positions as shown below:

\section{Initial Positions}

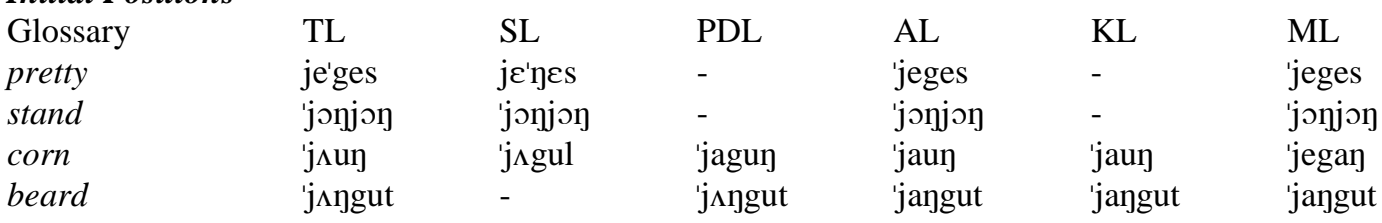




\begin{tabular}{|c|c|c|c|c|c|c|}
\hline finger & 'j $\Lambda \mathrm{ri}$ & 'jᄉri & 'jari & 'j $\Lambda \mathrm{ri}$ & 'jari & j $\Lambda$ ri \\
\hline meet & jumpa & 'juppan & 'juppah & 'jumpa & - & 'jumpa \\
\hline \multicolumn{7}{|c|}{ Middle Positions } \\
\hline Glossary & $\mathrm{TL}$ & SL & PDL & $\mathrm{AL}$ & KL & ML \\
\hline stand & 'jonjon & 'jonjon & - & 'jonjon & - & 'jonjon \\
\hline tired & 'loj & 'loj & le'ja & 'loj $\Lambda$ & - & 'loj \\
\hline spit & 'tijur & 'tujur & - & 'tijur & - & - \\
\hline sharp & ta'jom & - & 'tajem & ta'jom & - & ta'jom \\
\hline
\end{tabular}

The method of reconstruction applied above is used to reconstruct the proto-phoneme of $/ \mathrm{j}-\mathrm{j}-\mathrm{j}-\mathrm{j}-\mathrm{j}-\mathrm{j} /$. In the above data, the sounds in correspondence set $/ \mathrm{j}-\mathrm{j}-\mathrm{j}-\mathrm{j}-\mathrm{j}-\mathrm{j} /$ in initial and middle positions are the same, namely /j/ in TL, SL, PDL, AL, KL, and ML. In other words, it can be stated that the sounds are linearly inherited from the same sound. On the basis of the fact, the reconstruction of the sound correspondence set is conducted by choosing $/ *_{\mathrm{j}}$ / as its proto-phoneme since its reflex is the same in all six sister languages.

The distributions of $/ \mathrm{j} /$ is as follows:<smiles>[I-][I-]</smiles>

\subsubsection{Sound Correspondence set $/ r-r-r-r-r-r /$}

Sound correspondence set /r-r-r-r-r-r/ in BLs occurs regularly and recurrently in initial, middle, and final positions as shown below:

\begin{tabular}{|c|c|c|c|c|c|c|}
\hline \multicolumn{7}{|c|}{ Initial Positions } \\
\hline Glossary & $\mathrm{TL}$ & SL & PDL & $\mathrm{AL}$ & KL & ML \\
\hline mosfly & 'ronit & 'ronit & - & 'ronit & 'rejit & 'ronit \\
\hline $\operatorname{sing}$ & ' $\varepsilon \mathrm{dd} \varepsilon$ & - & 'End $\varepsilon$ & ' $\varepsilon \mathrm{dd} \varepsilon$ & ' $\varepsilon$ nd $\varepsilon$ & - \\
\hline deligent & $\operatorname{rin}^{\prime} g_{\Lambda} \mathrm{S}$ & $\operatorname{rin}^{\prime} g \Lambda s$ & - & $\operatorname{rin}^{\prime} g \Lambda s$ & - & $\operatorname{rin}^{\prime} g \Lambda S$ \\
\hline hundred & 'ratus & 'ratus & 'ratus & 'ratus & 'ratus & 'ratus \\
\hline thousand & 'ribu & 'ribu & 'ribu & 'ribu & 'ribu & 'ribu \\
\hline \multicolumn{7}{|c|}{ Middle Positions } \\
\hline Glossary & TL & SL & PDL & $\mathrm{AL}$ & KL & ML \\
\hline$d r y$ & - & 'horah & ke'rah & - & ke'rah & 'korin \\
\hline night & 'bornin & 'bornin & 'bernin & 'bornin & 'bernin & 'bornin \\
\hline pasir & - & 'horsik & - & 'horsik & ker'sik & 'horsik \\
\hline pull & 'tarik & - & 'tarik & 'tarik & 'tarik & 'tarik \\
\hline bright & 'torang & 'terang & - & 'torang & 'terang & 'torang \\
\hline \multicolumn{7}{|c|}{ Final Positions } \\
\hline Glossary & $\mathrm{TL}$ & SL & PDL & $\mathrm{AL}$ & KL & ML \\
\hline swollen & - & - & - & 'bosar & 'besar & 'bosar \\
\hline full & 'bosur & 'bosur & 'bosur & 'besur & - & 'bosur \\
\hline dirtty & 'kotor & - & 'kotor & 'kotor & - & 'kotor \\
\hline straight & ti'gor & - & 'teger & ti'gor & - & - \\
\hline white & bot'tar & - & 'mbentar & bot'tar & 'bentar & bon'tar \\
\hline
\end{tabular}

The method of reconstruction applied above is used to reconstruct the proto-phoneme of /r-r-r-r-r-r/. In the above data, the sounds in correspondence set /r-r-r-r-r-r/ in initial, middle, and final positions are the same, namely $/ r$ / in TL, SL, PDL, AL, KL, and ML. In other words, it can be stated that the sounds are linearly inherited from the same sound. On the basis of the fact, the reconstruction of the sound correspondence set is conducted by choosing $/ * \mathrm{r} /$ as its proto-phoneme since its reflex is the same in all six sister languages.

The distribution of $/ \mathrm{r} /$ is as follows:

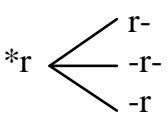

\subsubsection{Sound CorrespondenceSet /-l-l-l-l-l/}

Sound correspondence set /1-1-1-1-1-1/ in BLs occurs regularly and recurrently in initial, middle, and positions as shown below: 


\begin{tabular}{|c|c|c|c|c|c|c|}
\hline Glossary & $\mathrm{TL}$ & SL & PDL & $\mathrm{AL}$ & KL & ML \\
\hline run & 'lojon & - & 'lojan & 'lojon & - & 'lojon \\
\hline escape & 'lus & 'lush & 'luah & 'lus & - & 'lus \\
\hline forget & 'lupa & 'lupa & 'lupa & 'lupa & 'lupa & 'lupa \\
\hline tired & 'loj $\Lambda$ & 'loj $\Lambda$ & le'ja & 'loj $\Lambda$ & - & 'loj $\Lambda$ \\
\hline slippery & $1 \wedge$ d'dit & lan'dit & 'ndalit & lan'dit & 'dalit & lan'dit \\
\hline \multicolumn{7}{|c|}{ Middle Positions } \\
\hline Glossary & $\mathrm{TL}$ & SL & PDL & $\mathrm{AL}$ & KL & ML \\
\hline induce & 'elek & 'عlعk & - & 'clek & - & 'عlعk \\
\hline hill & 'dolok & 'dolok & de'ley & - & de'len & 'dolok \\
\hline moon & 'bulın & 'bulın & 'bulın & 'bulın & 'bulın & 'bulın \\
\hline eight & u'slu & 'wsluh & 'waluh & - & 'waluh & - \\
\hline walk & 'd $\Lambda l_{\Lambda} n$ & 'd $\Lambda 1 \Lambda \mathrm{n}$ & 'dalan & 'dalan & 'dalan & 'dalan \\
\hline three & 'tolu & 'tolu & te'lu & 'tolu & te'lu & 'tolu \\
\hline \multicolumn{7}{|c|}{ Final Positions } \\
\hline Glossary & $\mathrm{TL}$ & SL & PDL & $\mathrm{AL}$ & KL & ML \\
\hline$d u d u k$ & 'huddul & 'hundul & 'kundul & - & 'kundul & - \\
\hline difficult & ma'ol & ma'ol & - & ma'ol & - & ma'ol \\
\hline thickl & ha'pal & - & 'kapal & ha'pal & 'kapal & ha'pal \\
\hline ear & 'pingol & 'pingol & - & 'pingol & - & - \\
\hline deaf & nع'ngl & nع'nعl & - & 'inol & - & 'inol \\
\hline
\end{tabular}

The method of reconstruction applied above is used to reconstruct the proto-phoneme of /1-1-1-1-1-1/. In the above data, the sounds in correspondence set /1-1-1-1-1-1/ in initial, middle, and final positions are the same, namely /l/ in TL, SL, PDL, AL, KL, and ML. In other words, it can be stated that the sounds are linearly inherited from the same sound. On the basis of the fact, the reconstruction of the sound correspondence set is conducted by choosing $/ * 1 /$ as its proto-phoneme since its reflex is the same in all the six sister languages.

The distribution of $/ 1 /$ is as follows:<smiles></smiles>

\subsubsection{Sound Correspondence Set /n-15-15-15-n-n/}

Sound correspondence set $/ \eta-\eta-\eta-\eta-\eta-\eta /$ in BLs occurs regularly and recurrently in middle and final positions as shown below:

\section{Middle Positions}

\begin{tabular}{|c|c|c|c|c|c|c|}
\hline Glossary & $\mathrm{TL}$ & SL & PDL & $\mathrm{AL}$ & $\mathrm{KL}$ & ML \\
\hline beard & 'jıygut & - & 'jaygut & 'jangut & 'jangut & 'jı̄gut \\
\hline eat & 'majan & 'majan & 'majan & 'mayan & 'man & 'majan \\
\hline back & taj'gurun & taj'guruy & - & taj'goru & 'goru & tan'gor \\
\hline stick & 'tukkot & 'tukkot & 'tonket & 'tukkot & "topkat & 'tujkst \\
\hline ear & 'pingol & 'pingol & - & 'pingol & - & - \\
\hline \multicolumn{7}{|c|}{ Final Positions } \\
\hline Glossary & $\mathrm{TL}$ & SL & PDL & $\mathrm{AL}$ & KL & ML \\
\hline $\operatorname{dog}$ & 'bi^ך & b 'li $^{\prime} \mathrm{y}$ & 'bi^ך & - & 'bi^y & - \\
\hline meat & 'd $\Lambda$ gin & - & 'dıgin & - & 'dıgin & - \\
\hline berak & 'mitin & - & 'micin & 'mitin & - & 'mitin \\
\hline ar & 'bittan & 'bittan & 'bintay & 'bintan & 'bintan & 'bintan \\
\hline blind & 'pitun & 'pitun & 'pitun & 'petun & - & - \\
\hline leaf & 'bulun & 'bulun & 'bulun & 'bulun & 'buluy & 'bulun \\
\hline
\end{tabular}

The method of reconstruction applied above is used to reconstruct the proto-phoneme of $/ \eta-\eta-\eta-\eta-\eta$ -

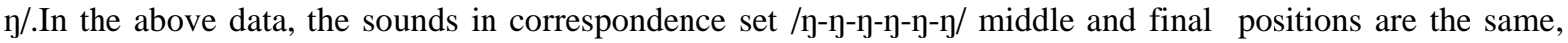
namely $/ \mathrm{y} /$ in TL, SL, PDL, AL, KL, and ML. In other words, it can be stated that the sounds are linearly inherited from the same sound. On the basis of the fact, the reconstruction of the sound correspondence set is conducted by choosing $/ * \mathrm{n} /$ as its proto-phoneme since its reflex is the same in all six sister languages.

The distribution of $/ \mathrm{y} /$ is as follows: 
<smiles>[3H][Te][3H]</smiles>

\subsubsection{Sound Correspondence Set $/ p-p-p-p-p-p /$}

Sound correspondence set /p-p-p-p-p-p/ in BLs occurs regularly and recurrently in initial, middle, and final positions as shown below:

\section{Initial Positions}

Glossary

young

bitter

shorth

navel

egg

Middle Positions

Glossary

four

cotton

hut

narrow

thin

whistle

Final Positions

Glossary

dark

suck

hold

catch

$\begin{array}{ll}\text { TL } & \text { SL } \\ \text { po'so } & \text { po'so } \\ \text { pa'ct } & \text { pa' } \varepsilon t \\ - & \text { 'pondok } \\ \text { 'pusok } & \text { 'pusok } \\ \text { 'pira } & -\end{array}$

TL SL

'spat

'hapas

SL

'opat

'hapas

'sopo

sop'pit

rap'pis

'soppul

\section{PDL}

sop'pit

ni'pis

-

TL

-

'ossop

'tiop

'takkup
SL

'golap

'ossop

-

'takkap
PDL

'pagit

'pendek

-

-

em'pat

'kapas

'sapo

AL

po'so

pa'et

'pendek

'pucot

'pira

AL

'spat

'hapas

'sopo

sop'pit

'tipis

'tipis

'sumpul

PDL

'ngelap

'isap

'tankup

go'lap

'iccsp

'tiop

'takkup
KL

-

'pagit

-

'pusun

pilaru

KL

em'pat

'kapas

'sapo

-

'tipis

sem'pul

KL ge'lap

-

-

'tankap
ML

po'so

pa'et

'pon'dok

'pusst

'pira

ML

'spat

'hapas

'sopo

som'pit

'tipis

-

ML

go'lap

'incop

'tiop

'tankup

The method of reconstruction applied above is used to reconstruct the proto-phoneme of /p-p-p-p-p-p/. In the above data, the sounds in correspondence set /p-p-p-p-p-p/ in initial, middle, and final positions are the same, namely /p/ in TL, SL, PDL, AL, KL, and ML. In other words, it can be stated that the sounds are linearly inherited from the same sound. On the basis of the fact, the reconstruction of the sound correspondence set is conducted by choosing $/ * \mathrm{p} /$ as its proto-phoneme since its reflex is the same in all six sister languages.

The distribution of $/ \mathrm{p} /$ is as follows:<smiles>[Pb]1C2p3p1p32</smiles>

\subsubsection{Sound Correspondence Set /g-g-g-g-g-g/}

Sound correspondence set /g-g-g-g-g-g/ in BLs occurs regularly and recurrently in initial and middle positions as shown below:

\section{Initial Positions}

\begin{tabular}{|c|c|c|c|c|c|c|}
\hline Glossary & $\mathrm{TL}$ & SL & PDL & $\mathrm{AL}$ & KL & ML \\
\hline lie & 'gnbus & - & 'gubus & - & - & 'gubus \\
\hline sap & 'gota & 'gotah & 'getah & 'gota & - & 'gota \\
\hline strong & go'go & go'goh & - & go'go & 'gəgəh & go'go \\
\hline yellow & - & gor'sin & - & gor'sin & 'gersin & gor'sin \\
\hline \multicolumn{7}{|c|}{ Middle Positions } \\
\hline Glossary & TL & SL & PDL & $\mathrm{AL}$ & KL & ML \\
\hline disgusted & 'gigi & 'gigi & - & 'gigi & - & - \\
\hline if & 'ango & 'ango & 'ango & - & 'ango & - \\
\hline when & $\Lambda \mathrm{d}^{\prime} \operatorname{dig} \Lambda \mathrm{n}$ & an'digan & 'ndigan & an'digan & 'digan & an'digan \\
\hline sweet & ton'gi & - & tej'gi & toj'gi & - & - \\
\hline house & 'b $\Lambda g_{\Lambda} \mathrm{S}$ & - & 'bages & 'bagas & - & 'bagas \\
\hline
\end{tabular}


The method of reconstruction applied above is used to reconstruct the proto-phoneme of /g-g-g-g-g-g/. In the above data, the sounds in correspondence set /g-g-g-g-g-g/ in initial and middle positions are the same, namely /g/ in TL, SL, PDL, AL, KL, and ML. In other words, it can be stated that the sounds are linearly inherited from the same sound. On the basis of the fact, the reconstruction of the sound correspondence set is conducted by choosing $/ * \mathrm{~g} /$ as its proto-phoneme since its reflex is the same in all six sister languages.

The distribution of $/ \mathrm{g} /$ is as follows:<smiles>[B-][Se][B-]</smiles>

\subsection{Sound Correspondence Set /d-d-d-d-d-d/}

Sound correspondence set /d-d-d-d-d-d/ in BLs occurs regularly and recurrently in initial and middle positions as shown below:

\begin{tabular}{|c|c|c|c|c|c|c|}
\hline \multicolumn{7}{|l|}{ Initial Positions } \\
\hline Glossary & $\mathrm{TL}$ & SL & PDL & $\mathrm{AL}$ & KL & ML \\
\hline lake & - & - & 'danau & da'n๖ & 'danau & 'danau \\
\hline near & - & do'hor & - & do'nok & 'deher & do'nok \\
\hline world & - & du'nia & du'nia & du'nia & 'doni & du'nia \\
\hline torn & - & - & 'dori & - & 'duri & 'duri \\
\hline fall & $\mathrm{d} \Lambda^{\prime} \mathrm{bu}$ & $\mathrm{d} \Lambda^{\prime} \mathrm{bu}$ & - & $\mathrm{d} \Lambda^{\prime} \mathrm{bu}$ & dabuh & $\mathrm{d} \Lambda^{\prime} \mathrm{bu}$ \\
\hline \multicolumn{7}{|l|}{ Middle Positions } \\
\hline Glossary & $\mathrm{TL}$ & SL & PDL & AL & KL & ML \\
\hline rice & id'dahan & $\operatorname{in} d \Lambda h \wedge n$ & - & in'dahan & - & in'dahan \\
\hline sing & ' $\varepsilon$ dd $\varepsilon$ & - & ' $\varepsilon$ nd $\varepsilon$ & ' $\varepsilon$ dd $\varepsilon$ & en'de & - \\
\hline one & $\operatorname{s} \Lambda \mathrm{d} \Lambda$ & $\operatorname{s} \Lambda \mathrm{d} \Lambda$ & 'sada & 'sada & 'sada & 's $\Lambda \mathrm{d} \Lambda$ \\
\hline horn & 'tad'duk & 'tanduk & 'tanduk & 'tanduk & tandok & 'tanduk \\
\hline
\end{tabular}

The method of reconstruction applied above is used to reconstruct the proto-phoneme of /d-d-d-d-d-d/. In the above data, the sounds in correspondence set /d-d-d-d-d-d/ in initial and middle positions are the same, namely /d/ in TL, SL, PDL, AL, KL, and ML. In other words, it can be stated that the sounds are linearly inherited from the same sound. On the basis of the fact, the reconstruction of the sound correspondence set is conducted by choosing $/ * \mathrm{~d} /$ as its proto-phoneme since its reflex is the same in all six sister languages.

The distribution of $/ \mathrm{d} /$ is as follows:<smiles>ClC(Cl)Cl</smiles>

\subsection{Sound Correspondence Set /m-m-m-m-m-m/}

Sound correspondence set /m-m-m-m-m-m/ in BLs occurs regularly and recurrently in initial, middle, and final positions as shown below:

\section{Initial Positions}

\begin{tabular}{|c|c|c|c|c|c|c|}
\hline Glossary & $\mathrm{TL}$ & $\mathrm{SL}$ & PDL & $\mathrm{AL}$ & $\mathrm{KL}$ & $\mathrm{ML}$ \\
\hline shy & $\mathrm{m} \Lambda^{\prime} \mathrm{il} \Lambda$ & 'mela & 'mela & $m \Lambda^{\prime} \mathrm{il} \Lambda$ & 'mela & $\mathrm{m} \Lambda$ 'il $\Lambda$ \\
\hline die & 'mate & 'matei & 'mate & 'mate & 'mate & 'mate \\
\hline win & 'monay & 'monay & me'nan & 'monay & me'nay & 'monay \\
\hline drink & 'minum & 'minum & 'minum & 'minum & 'minum & 'minum \\
\hline vomit & 'mutı & 'mutah & 'mutah & 'muta & 'mutah & 'muta \\
\hline \multicolumn{7}{|c|}{ Middle Positions } \\
\hline Glossary & $\mathrm{TL}$ & $\mathrm{SL}$ & PDL & $\mathrm{AL}$ & $\mathrm{KL}$ & $\mathrm{ML}$ \\
\hline fat & mok'mok & - & 'ngəmっk & - & mok'mok & mok'mok \\
\hline right & sismun & si'hamun & ka'muhen & - & ka'muhen & - \\
\hline incense & ha'mijjon & ha'monan & keme'nyen & ha'monyan & keme'nyen & - \\
\hline moustache & 'kumi & 'gomis & 'kumis & 'kumis & 'kumis & 'kumis \\
\hline whistle & - & - & 'sumpul & 'ombus & sem'pul & 'ombus \\
\hline \multicolumn{7}{|c|}{ Final Positions } \\
\hline Glossary & $\mathrm{TL}$ & $\mathrm{SL}$ & PDL & $\mathrm{AL}$ & $\mathrm{KL}$ & $\mathrm{ML}$ \\
\hline cheek & 'hurum & 'huyum & - & - & 'kurum & - \\
\hline recover & 'malum & 'malum & 'malum & 'malum & 'malem & - \\
\hline
\end{tabular}




$\begin{array}{lllllll}\text { well } & \text { 'sumur } & \text { 'sumur } & \text { 'sumur } & \text { 'sumur } & \text { 'sumur } & \text { 'sumur } \\ \text { bury } & - & - & \text { 'tanem } & \text { 'tan`m } & - & \text { 'tanэm } \\ \text { sleep } & \text { 'modom } & \text { 'modom } & \text { me'dem } & \text { 'modom } & \text { me'dem } & \text { me'dem }\end{array}$

The method of reconstruction applied above is used to reconstruct the proto-phoneme of /m-m-m-m-m$\mathrm{m} /$. In the above data, the sounds in correspondence set $/ \mathrm{m}-\mathrm{m}-\mathrm{m}-\mathrm{m}-\mathrm{m}-\mathrm{m} /$ in initial and middle positions are the same, namely /m/ in TL, SL, PDL, AL, KL, and ML. In other words, it can be stated that the sounds are linearly inherited from the same sound. On the basis of the fact, the reconstruction of the sound correspondence set is conducted by choosing $/ * \mathrm{~m} /$ as its proto-phoneme since its reflex is the same in all six sister languages.

The distribution of $/ \mathrm{m} /$ is as follows:

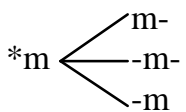

\subsection{Sound Correspondence Set \$s-s-s-s-s-s/}

Sound correspondence set /s-s-s-s-s-s/ in BLs occurs regularly and recurrently in initial, middle, and final positions as shown below:

\begin{tabular}{|c|c|c|c|c|c|c|}
\hline \multicolumn{7}{|c|}{ Initial Positions } \\
\hline Glossary & $\mathrm{TL}$ & SL & PDL & $\mathrm{AL}$ & KL & ML \\
\hline bite & - & - & 'sarut & sargut & - & sargut \\
\hline nail & si'silon & si'silon & si'selu & si'silon & si'lusilu & sa'silon \\
\hline damage & $\operatorname{seg} \Lambda$ & $\operatorname{sed} \Lambda$ & 'ceda & 'sego & 'ceda & $\operatorname{seg} \Lambda$ \\
\hline nine & 'si & 'sish & 'sibah & - & si'wah & - \\
\hline narrow & sop'pit & sop'pit & - & sop'pit & - & - \\
\hline glad & 'sonan & - & se'nay & 'sonan & 'sonay & 'sonan \\
\hline \multicolumn{7}{|c|}{ Middle Positions } \\
\hline Glossary & TL & SL & PDL & $\mathrm{AL}$ & KL & ML \\
\hline dumb & - & - & - & 'bisu & 'bisu & 'bisu \\
\hline chilly & lı'sink & $1 \Lambda^{\prime} \sin \Lambda$ & - & la'siak & - & la'siak \\
\hline breath & 'hosa & 'həsah & ke'sah & 'hosa & ke'sah & 'hosa \\
\hline who & 'ise & 'ise & 'ise & 'ise & 'ise & 'ise \\
\hline \multicolumn{7}{|c|}{ Final Positions } \\
\hline Glossary & $\mathrm{TL}$ & SL & PDL & $\mathrm{AL}$ & KL & ML \\
\hline smoke & 'timus & 'timus & - & 'timus & - & 'timus \\
\hline rice & 'boras & 'boras & 'beras & - & 'beras & - \\
\hline pretty & je'ges & jع'nعs & - & 'jeges & - & 'jeges \\
\hline languish & 'malos & 'melus & 'melus & malos & 'melus & malos \\
\hline hot & 'las & mi'lıs & - & mi'las & me'las & mi'las \\
\hline
\end{tabular}

The method of reconstruction applied above is used to reconstruct the proto-phoneme of /s-s-s-s-s-s/. In the above data, the sounds in correspondence set /s-s-s-s-s-s/ in initial and middle positions are the same namely /s/ in TL, SL, PDL, AL, KL, and ML. In other words, it can be stated that the sounds are linearly inherited from the same, sound. On the basis of the fact, the reconstruction of the sound correspondence set is conducted by choosing /*s/ as its proto-phoneme since its reflex is the same in all six sister languages.

The distribution of $/ \mathrm{s} /$ is as follows:<smiles>CC(C)(C)CS</smiles>

\subsection{Sound Correspondence Set /n-n-n-n-n-n/}

Sound correspondence set /n-n-n-n-n-n/ in BLs occurs regularly and recurrently in middleand final positions as shown below:

$\begin{array}{lllllll}\text { Middle Positions } & & & & & \\ \text { Glossary } & \text { TL } & \text { SL } & \text { PDL } & \text { AL } & \text { KL } & \text { ML } \\ \text { child } & \text { 'anak } & - & - & \text { 'anak } & \text { 'anak } & \text { 'anak } \\ \text { ayam } & \text { 'manuk } & - & \text { 'manuk } & \text { 'manuk } & \text { 'manuk } & \text { 'manuk } \\ \text { brave } & \text { 'ba'rani } & - & \text { be'rani } & - & - & \text { be'rani } \\ \text { hang } & - & - & \text { 'gantuy } & - & - & \text { 'gantuy }\end{array}$




\begin{tabular}{|c|c|c|c|c|c|c|}
\hline $\begin{array}{l}\text { mother } \\
\text { Final Positions }\end{array}$ & 'inoy & 'inan & 'inay & - & - & - \\
\hline Glossary & $\mathrm{TL}$ & SL & PDL & $\mathrm{AL}$ & $\mathrm{KL}$ & ML \\
\hline wind & 'ajin & - & 'anin & 'ajin & 'anin & 'ajin \\
\hline moon & 'bulın & 'bulın & 'bulın & 'bulın & 'bulın & 'bulın \\
\hline fish & - & 'ikın & 'ikan & 'ikın & - & 'ikın \\
\hline year & 'taon & 'tahun & 'tahun & 'taon & 'tahun & 'tahun \\
\hline hand & 'tajan & 'tajan & 'tajan & 'tajan & 'tan & 'tayan \\
\hline place & i'yanan & 'ianan & - & i'yanan & i'nan & - \\
\hline
\end{tabular}

The method of reconstruction applied above is used to reconstruct the proto-phoneme of /n-n-n-n-n-n/. In the above data, the sounds in correspondence set /n-n-n-n-n-n/ in middle and final positions are the same, namely /n/ in TL, SL, PDL, AL, KL, and ML. In other words, it can be stated that the sounds are linearly inherited from the same sound. On the basis of the fact, the reconstruction of the sound correspondence set is conducted by choosing $/ * \mathrm{n} /$ as its proto-phoneme since its reflex is the same in all six sister languages.

The distribution of $/ \mathrm{n} /$ is as follows:

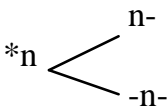

\subsection{Innovation-based SoundCorresponde Sets}

\subsubsection{Sound Correspondence Set / $-2-e-0-e-0 /$}

Sound correspondence set / $/-0-\mathrm{e}-\mathrm{\jmath}-\mathrm{e}-\mathrm{\jmath} /$ in BLs occurs regularly and recurrently in middle positions as shown below:

$\begin{array}{lllllll}\text { Glossary } & \text { TL } & \text { SL } & \text { PDL } & \text { AL } & \text { KL } & \text { ML } \\ \text { come } & \text { 'ro } & \text { 'roh } & \text { 'reh } & \text { 'ro } & \text { 'reh } & \text { 'ro } \\ \text { cold } & \text { 'borgs } & \text { 'borgoh } & \text { 'mbergoh } & - & \text { 'bergeh } & - \\ \text { four } & \text { 'opat } & \text { 'opat } & \text { 'empat } & \text { 'opat } & \text { 'empat } & \text { 'opat } \\ \text { tooth } & \text { 'ipon } & \text { 'epen } & \text { 'ipon } & \text { 'ipon } & \text { 'ipen } & \text { 'ipon } \\ \text { surprised } & \text { 'sojgot } & \text { 'senget } & \text { 'sojgot } & \text { 'sojgot } & \text { 'sejgot } & \text { 'sojgot }\end{array}$

According to Keraf (1991:61) and Crowley (1992:101), the sound that has the widest distribution in a correspondence set is reconstructed as the proto-phoneme. In The Comparative Method and Linguistic Reconstruction, http//en.wikipedia.org/wiki/Comparative method, thewidest distribution refers to mojoriy wins principle.

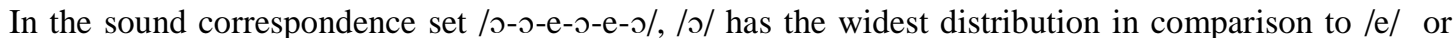
abides by majority wins principle. On the basis of the fact, the proto-phoneme of /っ-っ-e-っ-e-っ/ is reconstructed as /*o/.

The innovation of proto-phoneme /* $\mathrm{s} /$ into / $/$ and /e/ does not result in difference of meaning since the two reflexes in the sister languages are not distinctive. The varieties are not phonemic rather subphonemic or allophonic. The innovation can be shown in the following diagram:

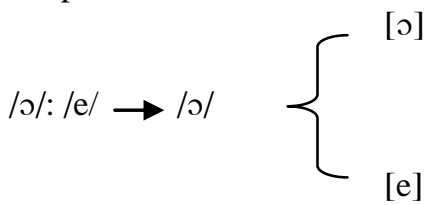

The rule of the sound change is / / changes into /e/ in PDL and KL due to the lenition or weakening of rounded back central / $/$ to become unrounded centeral low /e/ between two consonants. $* \mathrm{e} \rightarrow \mathrm{e} / \mathrm{C} \_\mathrm{C}$ in PDL and $\mathrm{KL}$

\subsubsection{Sound Correspondence Set /o-o-e-o-e-o/}

Sound correspondence set /o-o-e-o-e-o/ in BLs occurs regularly and recurrently in middle positions as shown below:

$\begin{array}{lllllll}\text { Glossary } & \text { TL } & \text { SL } & \text { PDL } & \text { AL } & \text { KL } & \text { ML } \\ \text { bile } & \text { pogu } & \text { pogu } & \text { peggu } & \text { pogu } & \text { pegu } & \text { pogu } \\ \text { dark } & - & \text { golap } & \text { ngelap } & \text { golap } & \text { gelap } & \text { golap } \\ \text { lebih } & \text { 'lobi } & - & \text { 'lebih } & \text { 'lobi } & - & \text { 'lobi }\end{array}$


three 'tolu tolu te'lu tolu te'lu tolu

In the sound correspondence set /o-o-e-o-e-o/, /o/ has the widest distribution in comparison to /e/ or abides by majority wins principle. On the basis of the fact, the proto-phoneme of /o-o-e-o-e-o/ is reconstructed as $/ * \mathrm{o} /$.

The innovation of proto-phoneme /*o/ into / / and /e/ does not result in difference of meaning since the two reflexes in the sister languages are not distinctive. The varieties are not phonemic rather subphonemic or allophonic. The innovation can be shown in the following diagram:

$/ \mathrm{o} /: / \mathrm{e} / \rightarrow \mathrm{o} /\left\{\begin{array}{c}{[\mathrm{o}]} \\ {[\mathrm{e}]}\end{array}\right.$

The rule of the sound change is /o/ changes into /e/ in PDL and KL due to the lenition or weakening of rounded back central /o/ to become unrounded centeral low /e/ between two consonants.

$*_{\mathrm{O}} \rightarrow \mathrm{e} / \mathrm{C} \_\mathrm{C}$ in PDL and $\mathrm{KL}$

\subsubsection{Sound Correspondence Set $\mid \varepsilon-e i-\varepsilon-\varepsilon-e-\varepsilon /$}

Sound correspondence set $/ \varepsilon-\mathrm{ei}-\varepsilon-\varepsilon-\mathrm{e}-\varepsilon /$ in BLs occurs regularly and recurrently in final positions as shown below:

\begin{tabular}{|c|c|c|c|c|c|}
\hline $\begin{array}{l}\text { Glossary } \\
\text { die }\end{array}$ & $\begin{array}{l}\text { TL } \\
\text { 'mat } \varepsilon\end{array}$ & $\begin{array}{l}\text { SL } \\
\text { 'matei }\end{array}$ & $\begin{array}{l}\text { PDL } \\
\text { 'mate }\end{array}$ & $\begin{array}{l}\text { AL } \\
\text { 'mate }\end{array}$ & $\begin{array}{l}\text { KL } \\
\text { 'mate }\end{array}$ \\
\hline corpse & bakke & bakkei & bayke & - & - \\
\hline foot & - & nahei & neh & - & nahe \\
\hline paddy & $\varepsilon m \varepsilon$ & omei & - & $\varepsilon \mathrm{m} \varepsilon$ & - \\
\hline
\end{tabular}

In the sound correspondence set $/ \varepsilon-\mathrm{ei}-\varepsilon-\varepsilon-\varepsilon-\varepsilon /, / \varepsilon /$ has the widest distribution in comparison to /ei/ or abides by majority wins principle. On the basis of the fact, the proto-phoneme of $/ \varepsilon-\mathrm{ei}-\varepsilon-\varepsilon-\varepsilon-\varepsilon /$ is reconstructed as $/ * \varepsilon /$.

The innovation of proto-phoneme /* $\varepsilon /$ into $/ \varepsilon /$ and /ei/ does not result in difference of meaning since the two reflexes in the sister languages are not distinctive. The varieties are not phonemic rather subphonemic or allophonic. The innovation can be shown in the following diagram:<smiles>ClCCC(Cl)Cl</smiles>

The rule of the sound change is $/ \varepsilon /$ changes into/ei/ in SL due to the vowel breaking (typically, off glide) processin which unrounded /i/ is added to / $\varepsilon /$ after which $/ \varepsilon /$ weakens to become /e/, resulting in diphthong/ei/ in the final positions.

$* \varepsilon \rightarrow \mathrm{ei} / \ldots$ in $\mathrm{SL}$

\subsubsection{Sound Correspondence Set $/ \Lambda-\Lambda-a-\Lambda-a-\Lambda /$}

Sound correspondence set $/ \Lambda-\Lambda-\mathrm{a}-\Lambda-\mathrm{a}-\Lambda /$ in BLs occurs regularly and recurrently in middle positions as shown below:

$\begin{array}{lllllll}\text { Glossary } & \mathrm{TL} & \mathrm{SL} & \mathrm{PDL} & \mathrm{AL} & \mathrm{KL} & \mathrm{ML} \\ \text { stale } & \mathrm{b} \Lambda \mathrm{ri} & \mathrm{b} \Lambda \mathrm{si} & \text { mbari } & \mathrm{b} \Lambda \mathrm{ri} & \text { mali } & \mathrm{b} \Lambda \mathrm{ri} \\ \text { deep } & \mathrm{b} \Lambda \mathrm{g} \Lambda \mathrm{S} & \mathrm{b} \Lambda \mathrm{g} \Lambda \mathrm{S} & \text { mbages } & \mathrm{b} \Lambda \mathrm{g} \Lambda \mathrm{S} & \mathrm{b} a g e s & \mathrm{~b} \Lambda \mathrm{g} \Lambda \mathrm{S} \\ \text { far } & \mathrm{d} \Lambda \mathrm{O} & \mathrm{d} \Lambda \mathrm{O} & \text { ndaəh } & \mathrm{d} \Lambda \mathrm{O} & \mathrm{d} \Lambda \mathrm{o} & \mathrm{d} \Lambda \mathrm{O}\end{array}$

In the sound correspondence set $/ \Lambda-\Lambda-\mathrm{a}-\Lambda-\mathrm{a}-\Lambda /, / \Lambda /$ has the widest distribution in comparison to $/ \mathrm{a} /$ or abides by majority wins principle. On the basis of the fact, the proto-phoneme of $/ \Lambda-\Lambda-a-\Lambda-a-\Lambda /$ is reconstructed as $/ *_{\Lambda} /$. 
The innovation of proto-phoneme $/ *_{\Lambda} /$ into $/ \Lambda /$ and $/ \mathrm{a} /$ does not result in difference of meaning since the two reflexes in the sister languages are not distinctive. The varieties are not phonemic rather subphonemic or allophonic. The innovation can be shown in the following diagram:

$\mid \Lambda /: / \mathrm{a} / \rightarrow / \mathrm{a} /\left\{\begin{array}{c}{[\mathrm{\Lambda}]} \\ \\ {[\mathrm{a}]}\end{array}\right.$

The rule of the sound change is $/ \Lambda$ / changes into /a/ in PDL and KL due to the lenition or weakening of unrounded central back $/ \Lambda /$ to become unrounded low back in middle positions between two consonants and between consonant and vowel.

$*_{\Lambda} \rightarrow \mathrm{a} / \mathrm{C} \_\mathrm{C}$ in PDL and $\mathrm{KL}$

C V

\subsubsection{Sound Correspondence Set /u-u-o-u-u-u/}

Sound correspondence set /u-u- - - $\mathrm{u}-\mathrm{u}-\mathrm{u} /$ in BLs occurs regularly and recurrently in middle positions as shown below:

Glossary

moustache

curcuma

cat

TL

'kumis

hunik

SL

gumis

hunin

PDL

hutin 'gomis

honin

kocin
$\mathrm{AL}$

'kumis

hunik

hutin
KL

'kumis

kunin

kucin
ML

'kumis

hunik

In sound correspondence set $/ \mathrm{u}-\mathrm{u}-\mathrm{o}-\mathrm{u}-\mathrm{u}-\mathrm{u} /, \mathrm{u} / \mathrm{has}$ the widest distribution in comparison to $/ \mathrm{J} /$ or abides by majority wins principle. On the basis of the fact, the proto-phoneme of $/ \mathrm{u}-\mathrm{u}-\mathrm{-}-\mathrm{u}-\mathrm{u}-\mathrm{u} /$ is reconstructed as $/ * \mathrm{u} /$.

The innovation of proto-phoneme $/ * \mathrm{u} /$ into $/ \mathrm{u} /$ and $/ \mathrm{o} /$ does not result in difference of meaning since the two reflexes in the sister languages are not distinctive. The varieties are not phonemic rather subphonemic or allophonic. The innovation can be shown in the following diagram:

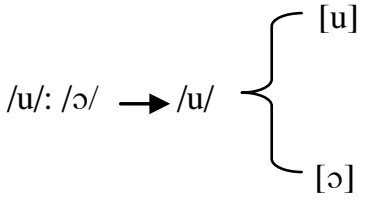

The rule of the sound change is $/ * \mathrm{u} /$ changes into $/ \mathrm{\rho} /$ in PDL due to the lenition or weakening of rounded high back $/ \mathrm{u} /$ to become rounded low back $/ \mathrm{\rho} /$ in middle positions between two consonants. $*_{\mathrm{u}} \rightarrow \mathrm{s} / \mathrm{C} \_\mathrm{C}$ in PDL

\subsubsection{Sound Correspondence Set h-i-i-i-e-i/}

Sound correspondence set /i-i-i-i-e-i/ in BLs occurs regularly and recurrently in middle positions as shown below:

$\begin{array}{lllllll}\text { Glos } & \text { TL } & \text { SL } & \text { PDL } & \text { AL } & \text { KL } & \text { ML } \\ \text { calf } & \text { 'bitis } & \text { 'bitis } & \text { bitis } & \text { bitis } & \text { bites } & \text { bitis } \\ \text { lips } & \text { 'bibir } & \text { bibir } & \text { bibir } & \text { bibir } & \text { biber } & \text { bibir }\end{array}$

In the sound correspondence set /i-i-i-i-e-i/, /i/ hast he widest distribution in comparison to /i/ or abides by majority wins principle. On the basis of the fact, the proto-phoneme of $/ \mathrm{i}-\mathrm{i}-\mathrm{i}-\mathrm{i}-\mathrm{e}-\mathrm{i} /$ is reconstructed as/*i/.

The innovation of proto-phoneme / $* \mathrm{i} /$ into /i/ and /e/ does not result in difference of meaning since the two reflexes in the sister languages are not distinctive. The varieties are not phonemic rather subphonemic or allophonic.

The innovation can be shown in the following diagram:

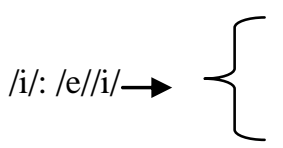


The rule of the sound change is $/ * \mathrm{i} /$ changes into /e/ in $\mathrm{KL}$ due to the lenition or weakening of unrounded high front $/ \mathrm{i} /$ to become unrounded centeral front /e/ in middle positions between two consonants. $*_{\mathrm{i}} \rightarrow \mathrm{e} / \mathrm{C} \_$Cin $\mathrm{KL}$

\subsubsection{Sound Correspondence Set/ $\phi-h-h-\phi-h-\phi /$}

Sound correspondence set $/ \phi-\mathrm{h}-\mathrm{h}-\phi-\mathrm{h}-\phi /$ in BLs occurs regularly and recurrently in final positions as shown below:

\begin{tabular}{|c|c|c|c|c|c|c|}
\hline $\begin{array}{l}\text { Glossary } \\
\text { bamboo }\end{array}$ & $\begin{array}{l}\text { TL } \\
\text { bulu }\end{array}$ & $\begin{array}{l}\text { SL } \\
\text { buluh }\end{array}$ & $\begin{array}{l}\text { PDL } \\
\text { buluh }\end{array}$ & $\begin{array}{l}\mathrm{AL} \\
\text { bulu }\end{array}$ & $\begin{array}{l}\text { KL } \\
\text { buluh }\end{array}$ & $\begin{array}{l}\text { ML } \\
\text { bulu }\end{array}$ \\
\hline half & bolı & - & bolıh & bols & - & bolı \\
\hline wash & buri & burih & buri & - & burih & buri \\
\hline come & ro & roh & roh & ro & roh & ro \\
\hline cold & borgo & borgoh & mbergoh & borgo & bergeh & borgo \\
\hline fall & $\mathrm{d} \Lambda \mathrm{bu}$ & $\mathrm{d} \Lambda$ buh & $\mathrm{d} \Lambda \mathrm{buh}$ & $\mathrm{d} \Lambda \mathrm{bu}$ & $\mathrm{d} \Lambda \mathrm{buh}$ & $\mathrm{d} \Lambda \mathrm{bu}$ \\
\hline
\end{tabular}

In reconstructing the proto-phoneme of $/ \phi-\mathrm{h}-\mathrm{h}-\phi-\mathrm{h}-\phi /$, the widest distribution or majority wins principle does not apply, for none of $/ \phi /$ and $/ \mathrm{h} /$ has the widest distribution. The occurances of the two sounds are equal, three times. The solution to it is to refer to what Crowley (1992:100) states that $/ \mathrm{R} / \mathrm{and} / \mathrm{h} /$ are sounds that are very commonly lost in languages. In BLs, the phenomenon exists. In Proto-Austronesian (PAN) descending BLs, the equivalents of rain retain sound /h/ as in/*hud'an/ in Wurm et al.(1978:164), /*hud'an/ (Dempwolf, 1938),/*huDan/ (Lopez,n.d.), /*hujan/ (Brandstetter and Dempwolf, 1943), and/*hud'an/ (Capell, 1943). In BLs, /*h/is lost to become/ud $\Lambda \mathrm{n} / \mathrm{in} \mathrm{TL}, \mathrm{SL}, \mathrm{PDL}, \mathrm{AL}, \mathrm{KL}$, and ML. Besides, in final position, there is /*h/ in the equivalent of bamboo/*buluh/ (Urm and Wilson, 1978:12). The sound is lost in TL, SL, AL, and ML to become /bulu/.

As of the loss of $/ * \mathrm{~h} /$, in regressive assimilation, $/ \mathrm{h} /$ is lost after changing into $/ \mathrm{k} / \mathrm{in} \mathrm{TL}$ as in /duy/ 'after'+ /ho/ 'you' $\rightarrow$ /duk'ks/'after you'. Based on it, it can be inferred that $/ \mathrm{h} /$ is lost from TL, AL, and ML. Consequently, /h/ can be reconstructed as the proto-phoneme of $/-\phi,-h,-h,-\phi,-h,-\phi /$.

The status of $/ * \mathrm{~h} /$ as proto-phoneme of $/-\phi,-\mathrm{h},-\mathrm{h},-\phi,-\mathrm{h},-\phi /$ is strengthened by the presence of the sound in initial position of the equivalent of come in Alas language (AL), the language which is very close to BLs as seen in the following:

$\begin{array}{lllllll}\text { TL } & \text { SL } & \text { PDL } & \text { AL } & \text { KL } & \text { ML } & \text { AL } \\ \text { "ro } & \text { 'roh } & \text { 'roh } & \text { 'ro } & \text { 'reh } & \text { 'ro } & \text { 'roh }\end{array}$

The rule of the sound change is $/ * \mathrm{~h} /$ changes into $/ \phi /$ in TL, SL, and ML due to the loss of the sound after vowel in the final position

$* \mathrm{~h} \rightarrow \phi / \ldots \#$ in TL,SL, and ML

$\mathrm{V}$

The innovation of proto-phoneme $/ * \mathrm{~h} /$ into $/ \mathrm{h} /$ and $/ \phi /$ does not result in difference of meaning since the two reflexes in the sister languages are not distinctive. The varieties are not phonemic rather subphonemic or allophonic. The innovation can be shown in the following diagram:<smiles>OCCC(CO)C[Hg]</smiles>

\subsubsection{Sound Correspondence Set $/ \phi-\phi-m-\phi-\phi-\phi \mid$} shown below:

Sound correspondence set $/ \phi-\phi-\mathrm{m}-\phi-\phi-\phi /$ in BLs occurs regularly and recurrently in initial positions as

$\begin{array}{lllllll}\text { Glossary } & \mathrm{TL} & \mathrm{SL} & \mathrm{PDL} & \mathrm{AL} & \mathrm{KL} & \mathrm{ML} \\ \text { stale } & \mathrm{b} \Lambda \mathrm{ri} & \mathrm{b} \Lambda \mathrm{si} & \text { mbari } & \mathrm{b} \Lambda \mathrm{ri} & \text { mali } & \mathrm{b} \Lambda \mathrm{ri} \\ \text { swollen } & - & - & \text { mbesar } & \text { bosar } & \text { besar } & \text { bosar } \\ \text { clean } & - & \text { borsih } & \text { mbersih } & - & \text { bersih } & - \\ \text { big } & \mathrm{b} \Lambda \lg \Lambda & \mathrm{b} \Lambda \mathrm{gg} \Lambda \mathrm{l} & \operatorname{mbelg} \mathrm{h} & - & - & - \\ \text { afraid } & \mathrm{bi} \mathrm{i} \mathrm{r} & \mathrm{bi} \Lambda \mathrm{r} & \operatorname{mbiar} & \text { biar } & \text { biar } & \text { biar }\end{array}$


In the sound correspondence set $/ \phi-\phi-\mathrm{m}-\phi-\phi-\phi /, / \phi /$ has the widest distribution in comparison to $/ \mathrm{m} /$ or abides by majority wins principle. On the basis of the fact, the proto-phoneme of $/ \phi-\phi-\mathrm{m}-\phi-\phi-\phi /$ is reconstructed as $/ * \phi /$.

The innovation of proto-phoneme $/{ }^{*} \phi /$ into $/ * \phi /$ and $/ \mathrm{m} /$ does not result in difference of meaning since the two reflexes in the sister languages are not distinctive. The varieties are not phonemic rather subphonemic or allophonic. The innovation can be shown in the following diagram:

$|\phi /: / \mathrm{m} / \rightarrow| \phi /\left\{\begin{array}{l}{[\phi]} \\ {[\mathrm{m}]}\end{array}\right.$

The rule of the sound change is $/ * \phi /$ changes into $/ \mathrm{m} /$ in PDL due to the addition (prothesis) of $/ \mathrm{m} /$ before voiced stop bilabial $/ * \mathrm{~b} /$ in initial position.

$* \phi \rightarrow \mathrm{m} / \ldots \mathrm{C}$ in PDL

\subsubsection{Sound Correspondence Set $/ \phi-\phi-n-\phi-\phi-\phi \mid$}

Sound correspondence set $/ \phi-\phi-n-\phi-\phi-\phi /$ in BLs occurs regularly and recurrently in initial positions as shown below:

\begin{tabular}{|c|c|c|c|c|c|}
\hline Glossary & $\mathrm{TL}$ & SL & PDL & $\mathrm{AL}$ & $\mathrm{KL}$ \\
\hline fall & $\mathrm{d} \Lambda^{\prime} \mathrm{bu}$ & 'd $\Lambda \mathrm{bu}$ & 'ndabuh & 'dabu & 'dabu \\
\hline far & $\mathrm{d} \Lambda^{\prime} \mathrm{O}$ & 'd $\Lambda \mathrm{O}$ & 'ndash & $\mathrm{d} \Lambda^{\prime} \mathrm{O}$ & 'd $\Lambda \supset h$ \\
\hline lick & 'dilıt & 'dilıt & 'ndilıt & 'dilnt & 'dilıt \\
\hline long & - & 'dokah & nde'kah & - & de'kah \\
\hline bright & - & - & nte'raך & to'ray & to'ran \\
\hline
\end{tabular}

In the sound correspondence set $/ \phi-\phi-n-\phi-\phi-\phi /, / \phi /$ has the widest distribution in comparison to $/ \mathrm{n} /$ or abides by majority wins principle.On the basis of the fact, the proto-phoneme of $/ \phi-\phi-n-\phi-\phi-\phi /$ is reconstructed as $/ * \phi /$.

The innovation of proto-phoneme $/{ }^{*} \phi /$ into $/{ }^{*} \phi /$ and $/ \mathrm{n} /$ does not result in difference of meaning since the two reflexes in the sister languages are not distinctive. The varieties are not phonemic rather subphonemic or allophonic. The innovation can be shown in the following diagram:<smiles>CC(CCCl)OCCO</smiles>

The rule of the sound change is $/ *^{*} \phi$ /changes into /n/ in PDL due to the addition (prothesis) of /n/ before voiced stop alveolar $/ * \mathrm{t} /$ and voiceless stop alveolar in initial positions.

$*_{\phi} \rightarrow \mathrm{n} / \ldots$ C in PDL

\subsubsection{Sound Correspondence Set $/ \phi-\phi-1-\phi-\phi-\phi \mid$}

Sound correspondence set $/ \phi-\phi-\eta-\phi-\phi-\phi /$ in BLs occurs regularly and recurrently in initial positions as shown below:

\begin{tabular}{|c|c|c|c|c|c|c|}
\hline $\begin{array}{l}\text { Glossary } \\
\text { strong }\end{array}$ & $\begin{array}{l}\text { TL } \\
\text { go'go }\end{array}$ & $\begin{array}{l}\text { SL } \\
\text { go'go }\end{array}$ & $\begin{array}{l}\text { PDL } \\
\text { 'ygego }\end{array}$ & $\begin{array}{l}\text { AL } \\
\text { go'go }\end{array}$ & $\begin{array}{l}\text { KL } \\
\text { 'gege }\end{array}$ & $\begin{array}{l}\text { ML } \\
\text { go'go }\end{array}$ \\
\hline dark & - & 'golap & jgelap & 'golap & 'gelap & 'golap \\
\hline yellow & - & 'gorsin & 'ngersin & 'gorsin & 'gersin & rsin \\
\hline long & $g \wedge j^{\prime} j \wedge \eta$ & $g_{\Lambda} n^{\prime} j \Lambda \eta$ & 'ngenay & gin'jay & 'geday & sin'jay \\
\hline
\end{tabular}

In the sound correspondence set $/ \phi-\phi-\eta-\phi-\phi-\phi /, / \phi /$ has the widest distribution in comparison to $/ \mathrm{\eta} /$ or abides by majority wins principle.On the basis of the fact, the proto-phoneme of $/ \phi-\phi-\eta-\phi-\phi-\phi /$ is reconstructed as $/ * \phi$ 
The innovation of proto-phoneme $/ * \phi /$ into $/ * \phi /$ and $/ \mathrm{n} /$ does not result in difference of meaning since the two reflexes in the sister languages are not distinctive. The varieties are not phonemic rather subphonemic or allophonic.

The innovation can be shown in the following diagram:<smiles>CCC(CO)OCCO</smiles>

The rule of the sound change is $/ * \phi /$ changes into $/ \mathrm{y} /$ in PDL due to the addition (prothesis) of $/ \mathrm{y} /$ before voiced stop velar $/ * \mathrm{~g} /$ in initial positions.

$* \phi \rightarrow \mathrm{y} / \ldots \mathrm{C}$ in PDL

\subsubsection{Sound Correspondence Set M-h-k-h-k-h/}

Sound correspondence set /h-h-k-h-k-h/ in BLs occurs regularly and recurrently in initial positions as shown below:

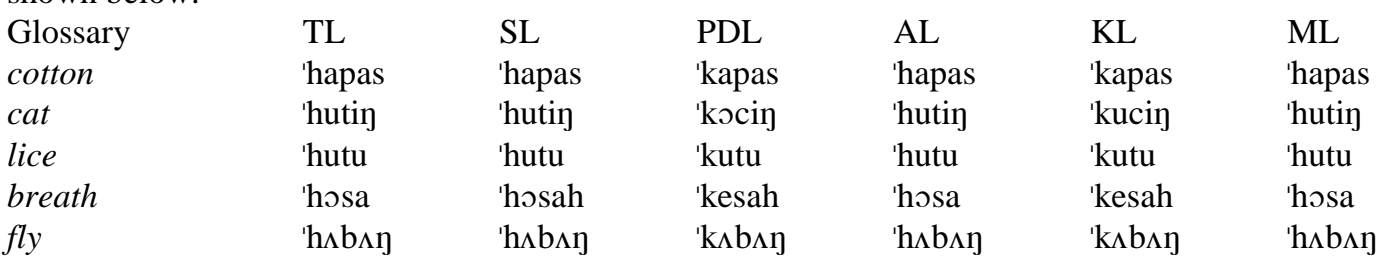

In accordance with the majority wins principle, the proto-phoneme of /h-h-k-h-k-h/ must be /*h/ for it has the widest distribution, in initial positions of TL, SL, AL, and ML in comparison to / $/ \mathrm{k} /$ of which distribution is only in PDL and KL. However, the reconstruction does not apply in the reconstruction of protophoneme of /h-h-k-h-k-h/ because /h/ has been reconstructed as proto-phoneme of / $\phi$-h-h- $\phi-\mathrm{h}-\phi /$.

Because of it, the data of BLs should be extended by including the data of AL and Bahasa Indonesia (BI).According to Panggabean (1994:178), the equivalent of cotton in AL is /kapas/ and according to Sugono et. al (2008:621), the equivalent of the word in BI is /kapas/. Provided that AL and BI data for the equivalent of cotton are included, there will be new correspondence set /h-h-k-h-k-h-k-k/ as seen below:

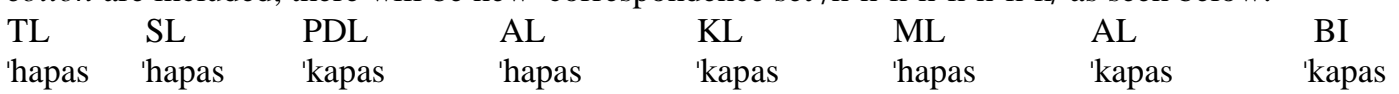

However, the data extension cannot bring about the proto-phoneme of $/ \mathrm{h}-\mathrm{h}-\mathrm{k}-\mathrm{h}-\mathrm{k}-\mathrm{h} / \mathrm{since} / \mathrm{h} /$ and $/ \mathrm{k} /$ respectively occur four times and none of them has the widest distribution. Thanks to it, the datum of the language in the higher level, PAN, needs to be referred to.

According to (Wurm and Wilson,1978), the equivalent of the word cotton is /kapas/ in Lopez (n.d.) and /kapes/in Charles (1973).

Following the inclusion of the data of $\mathrm{AL}, \mathrm{BI}$, and PAN, the distribution of $/ \mathrm{k} /$ is dominant. Consequently, $/ * \mathrm{k} /$ is reconstructed as proto-phoneme of $/ \mathrm{h}-\mathrm{h}-\mathrm{k}-\mathrm{h}-\mathrm{k}-\mathrm{h} /$. The innovation of $/ * \mathrm{k} /$ to become $/ \mathrm{h} /$ is summed up with the assumption that $/{ }^{*} \mathrm{k} /$ changes into $/ \mathrm{h} /(/ * \mathrm{k} />/ \mathrm{h} /)$ in $\mathrm{TL}, \mathrm{SL}, \mathrm{AL}$, and ML and undergoes retention in PDL and KL.

The innovation of proto-phoneme $/ * \mathrm{k} /$ into $/ * \mathrm{k} /$ and $/ \mathrm{h} /$ does not result in difference of meaning since the two reflexes in the sister languages are not distinctive. The varieties are not phonemic rather subphonemic or allophonic. The innovation can be shown in the following diagram:<smiles>N#[W]NC(C[AlH2])C[AlH2]</smiles>

The rule of the sound change is $/ * \mathrm{k} /$ changes into $/ \mathrm{h} /$ in $\mathrm{TL}, \mathrm{AL}$, and ML before vowel in initial position.

$*_{\mathrm{K}} \rightarrow \mathrm{h} / \# \_\mathrm{V}$ in TL, AL, and ML

\subsubsection{Sound Correspondence Set $k-k-\not-k-1-k /$}


Sound correspondence set /k-k-n-k-n-k/ in BLs occurs regularly and recurrently in middle positions as shown below:

$\begin{array}{lllllll}\text { Glossary } & \text { TL } & \text { SL } & \text { PDL } & \text { AL } & \text { KL } & \text { ML } \\ \text { catch } & \text { 'takkup } & \text { 'takkap } & \text { 'tajkap } & \text { 'takkap } & \text { 'tajkap } & \text { 'takkup } \\ \text { round } & \text { tik'ks } & - & \text { 'ntejks } & - & - & - \\ \text { corpse } & \text { 'bakke } & \text { bak'kei } & \text { 'bajke } & - & - & - \\ \text { stick } & \text { 'tukkot } & \text { 'tukkot } & \text { 'tujkst } & \text { 'tukkot } & \text { 'tujkst } & \text { 'tukkst }\end{array}$

Like in the reconstruction of $/ \phi$-h-h- $\phi-h-\phi /$, in the reconstruction of $/ k-k-\eta-k-\eta-k /$, the widest distribution or majority wins principle does not apply.

To reconstruct the proto-phoneme of the correspondence set, we refer to the principle stated by Crowley (1992:96), "Any reconstruction should involve sound changes that are plausible." He says that lenition is more likely to take place than fortition by giving example that $/ * \mathrm{k} /$ becomes $/ * \mathrm{R} /(/ * \mathrm{k} />/ * \mathrm{r} /$ is more likely to take place than $/ * \mathrm{r} /$ becomes $/ \mathrm{k} /(/ * \mathrm{r} />/ \mathrm{k} /)$.

However the example does not cover the question which one is more likely to take place $/ * \mathrm{y} /$ becomes $/ \mathrm{k} /(/ * \mathrm{y} />/ \mathrm{k} /)$ than $/ * \mathrm{k} /$ becomes $/ \mathrm{j} /(/ * \mathrm{k} />/ \mathrm{y} /)$ since both of them have the same point of articulation namely, dorsavelar. Despite it, the plausibility of sound change principle can be implemented in finding out the solution to the problem whether $/ * \mathrm{n} /$ becomes $/ \mathrm{k} /(/ * \mathrm{n} />/ \mathrm{k} /)$ or $/ * \mathrm{k} /$ becomes $/ \mathrm{h} /(/ * \mathrm{k} />/ \mathrm{h} /)$.

Based on the plausibility, it can be singled out that $/ * \mathrm{y} /$ changes into $/ \mathrm{k} /(/ * \mathrm{y} />/ \mathrm{k} /)$ instead of $/ * \mathrm{k} /$ changes into $/ \mathrm{y} /(/ * \mathrm{k} />/ \mathrm{y} /)$.

There are two premises that can be put forward to prove it. Firstly, in written forms of all BLs, cluster phoneme $/ \mathrm{gk} /$ is used to record spoken form $/ \mathrm{kk} /$. For instance, the equivalent of the word cup are written orthographically as mangkuk/majkuk/ in all BLs but it is pronounced in two different ways, /majkuk/ in PDL, KL, and ML and /makkuk/ in TL, SL, and ML. On the basis of it, there is a strong ground to say that /*n/ changes into $/ \mathrm{k} /(/ * \mathrm{n} />/ \mathrm{k} /)$ instead of $/ * \mathrm{k} /$ changes into $/ \mathrm{h} /(/ * \mathrm{k} />/ \mathrm{h} /)$.

Secondly, in assimilation process in $\mathrm{TL}, / \mathrm{y} / \mathrm{tends}$ to be conditioned sound instead of conditioning sound. Concerning the tendency that sound tends to be modified by its environment, (Pike,1968:58) may be referred to. The change of $/ \mathrm{y} /$ into $/ \mathrm{k} /$ in the assimilation is shown below:

1. $/ \mathrm{y} /$ changes into $/ \mathrm{k} /$ when followed by the word with initial sound $/ \mathrm{p} /$ as in $/ \mathrm{dan} /$ 'not'+ /porlu/ 'neccessary' $\rightarrow$ /dakporlu / 'not neccessary'.

2. $/ \mathrm{y} /$ changes into $/ \mathrm{k} /$ when followed by the word with initial sound $/ \mathrm{h} /$ as in $/ \mathrm{dun} /$ 'after' $+/ \mathrm{h}$ / ' 'you' $\rightarrow$ /dukks/ 'after you'.

3. /y/ changes into /k/ when followed by the word with initial sound /s/ as in /day/ 'not'+ /saut/ 'happen' $\rightarrow$ /daksaut/ 'not happen'.

4. $/ \mathrm{y} /$ changes into $/ \mathrm{k} /$ when followed by the word with initial sound $/ \mathrm{t} /$ as in $/ \mathrm{manay} /$ 'or' $^{\prime}+/ \mathrm{tu \Lambda k}^{1} / \rightarrow$ /manaktusk/ 'or tuak'.

Sound $/ \mathrm{y} /$ is also conditioned by the other sounds in assimilation. According to (Sibarani:1997) in (Marice, 2010:211), / $\mathrm{y} /$ changes into $/ \mathrm{k} /$ when followed by the word with initial phoneme $/ \mathrm{p} /(/ \mathrm{l}+\mathrm{p} / \rightarrow / \mathrm{kp} /)$, into $/ \mathrm{k} /$ when followed by the word with initial phoneme $/ \mathrm{s} /(/ \mathrm{n}+\mathrm{s} / \rightarrow / \mathrm{ks} /)$, and into $/ \mathrm{k} /$ when followed by the word with initial phoneme $/ \mathrm{t} /(/ \mathrm{n}+\mathrm{t} / \rightarrow / \mathrm{kt} /)$.

For this reason, it can be presumed that in the history of development of BLS, $/ \mathrm{l} /$ changes into $/ \mathrm{k} /$ in TL. Following the change of/ $\mathrm{\eta} /$ into /k/ in TL, correspondence set /k-k- $-\mathrm{k}-\mathrm{\eta}-\mathrm{k} /$ becomes $/ \mathrm{\eta}-\mathrm{k}-\mathrm{\eta}-\mathrm{k}-\mathrm{\eta}-\mathrm{k} /$.

To support the plausibility of the change of $/ \mathrm{y} /$ into $/ \mathrm{k} /$, the AL's datum is referred to. In the language, the equavalent of the word stick is /toj'kat/ and the equivalent of the word catch is /taj'kap/ (See Panggabean 1994:125). The distributions of $/ \mathrm{y} /$ and $/ \mathrm{k} /$ after the change of $/ \mathrm{g} /$ into $/ \mathrm{k} /$ in $\mathrm{TL}$ and the inclusion of AL is shown below:

\begin{tabular}{|c|c|c|c|c|c|}
\hline $\begin{array}{l}\text { TL } \\
\text { tupkot } \\
\text { tajkup }\end{array}$ & $\begin{array}{l}\text { SL } \\
\text { 'tukkot } \\
\text { 'tajkap }\end{array}$ & $\begin{array}{l}\text { PDL } \\
\text { 'tonket } \\
\text { 'takkap }\end{array}$ & $\begin{array}{l}\text { AL } \\
\text { 'tukkot } \\
\text { 'takkap }\end{array}$ & $\begin{array}{l}\text { KL } \\
\text { 'tonkat } \\
\text { 'tạkap }\end{array}$ & $\begin{array}{l}\text { ML } \\
\text { 'tukkot } \\
\text { 'takkup }\end{array}$ \\
\hline
\end{tabular}

Based on the data $/ * \mathrm{n} /$ can be reconstructed as proto-phoneme of $/ \mathrm{k}-\mathrm{k}-\mathrm{n}-\mathrm{k}-\mathrm{n}-\mathrm{k} /$. The innovation of proto-phoneme $/ * \mathrm{n} /$ into $/ * \mathrm{n} /$ and $/ \mathrm{k} /$ does not result in difference of meaning since the two reflexes in the sister languages are not distinctive. The varieties are not phonemic rather subphonemic or allophonic. The innovation can be shown in the following diagram:

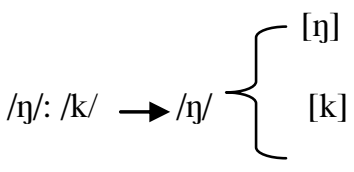

\footnotetext{
${ }^{1}$ tuak is traditional strong drink of Batak people
} 
The rule of the sound change is $/ *^{\mathrm{y}} /$ changes into/k/ in TL, SL, AL, and MLin middle positions before vowels.

$*_{\phi} \rightarrow \mathrm{y} / \ldots \mathrm{V} \quad$ in TL, SL, AL, and ML

\section{The Sub-grouping of BLs}

Crowley (1992:164-165) and Langacker (1992:339) say that shared innovation is used to establish the sub-grouping of sister languages. To carry out BLs'sub-grouping, the innovation-based correspondence sets of BLs are shown again below:

\begin{tabular}{|c|c|c|c|c|c|c|}
\hline & $\mathrm{TL}$ & SL & PDL & $\mathrm{AL}$ & $\mathrm{KL}$ & ML \\
\hline 1 & $\varnothing$ & $\mathrm{h}$ & $\mathrm{h}$ & $\varnothing$ & $\mathrm{h}$ & $\varnothing$ \\
\hline 2 & $\phi$ & $\phi$ & $\mathrm{m}$ & $\phi$ & $\phi$ & $\emptyset$ \\
\hline 3 & $\phi$ & $\phi$ & $\mathrm{n}$ & $\phi$ & $\phi$ & $\emptyset$ \\
\hline 4 & $\varnothing$ & $\phi$ & $\eta$ & $\phi$ & $\emptyset$ & $\emptyset$ \\
\hline 5 & $\mathrm{~h}$ & $\mathrm{~h}$ & $\mathrm{k}$ & $\mathrm{h}$ & $\mathrm{k}$ & $\mathrm{h}$ \\
\hline 6 & $\mathrm{k}$ & $\mathrm{k}$ & $\eta$ & $\mathrm{k}$ & $\eta$ & $\mathrm{k}$ \\
\hline 7 & 0 & o & $\mathrm{e}$ & 0 & $\mathrm{e}$ & 0 \\
\hline 8 & o & o & $\mathrm{e}$ & o & e & o \\
\hline 9 & $\varepsilon$ & ei & $\varepsilon$ & $\varepsilon$ & $\varepsilon$ & $\varepsilon$ \\
\hline 10 & $\Lambda$ & $\Lambda$ & $\mathrm{a}$ & $\Lambda$ & $\mathrm{a}$ & $\Lambda$ \\
\hline 11 & $\mathrm{u}$ & $\mathrm{u}$ & 0 & $\mathrm{u}$ & $\mathrm{u}$ & $\mathrm{u}$ \\
\hline 12 & $\mathrm{i}$ & $\mathrm{i}$ & $\mathrm{i}$ & $\mathrm{i}$ & e & $\mathrm{i}$ \\
\hline
\end{tabular}

Based on the above chart, it is revealed that in TL, AL, and ML in number $1 / * \mathrm{~h} /$ is lost in final position or $\mathrm{h} \rightarrow \phi / \ldots \#$ and in number $6 / * \mathrm{~g} /$ changes into $/ * \mathrm{k} /$ or $\mathrm{\eta} \rightarrow \mathrm{k} / \#$ __ \#. Such innovations do not occur in SL, PDL, and $\overline{\mathrm{KL}}$. Based on the shared innovation, TL, AL, and ML belong to one group.

In addition to the shared innovation, the three sister languages show closeness as seen in number 1,2 , $3,4,5,6,7,8,9,10,11$, and 12 .

Meanwhile, in PDL and bK, in number $7, / * \mathrm{~s} /$ changes into /e/ in middle position or $\mathrm{o} \rightarrow \mathrm{e} / \#$ \#, in number $8 / *_{\mathrm{o}} /$ changes into $/ \mathrm{e} /$ in middle position or $\mathrm{o} \rightarrow \mathrm{e} / \# \ldots \#$, and in number $10, / *_{\Lambda} /$ changes into $/ *_{\mathrm{a}} \mathrm{a} /$ or $\Lambda \rightarrow \mathrm{a} / \#$ \#. Such innovations do not occur in TL, SL, AL, and KL. Based on the shared innovation, PDL and KL belong to one group.

In addition to the shared innovation, the two sister languages show closeness as seen in number 1, 5, 6, $7,8,9$, and 11 .

In SL, /*ع/changes into /*ei/ in final positionor $\varepsilon \rightarrow$ ei / \#. Such innovation does not occur in the first group (TL-AL-ML) and in the second group (PDL-KL). Only SL does have diphthong. SL has another diphthong, namely /ou/ in the equivalent of hut, /sэpou/. Although SL shares similarities with TL-AL-ML as in number 5,6,7,8,10,11, and 12 leading to the possibility that it belongs to the group, it shares similarity with PDL-KL as in number 1. That means, sound innovation in SL is not consistent. Based on the inconsistency and the presence of diphthong in SL, this language is unique. Because of its unique characteristic, SL does not belong to TL-AL-ML and PDL-KL sub-proups.

Although SL is separated from TL-AL-ML and PDL-KL, it is closer to TL-AL-ML than to PDL-KL. The sub-grouping of BLs can be shown in the following diagram:

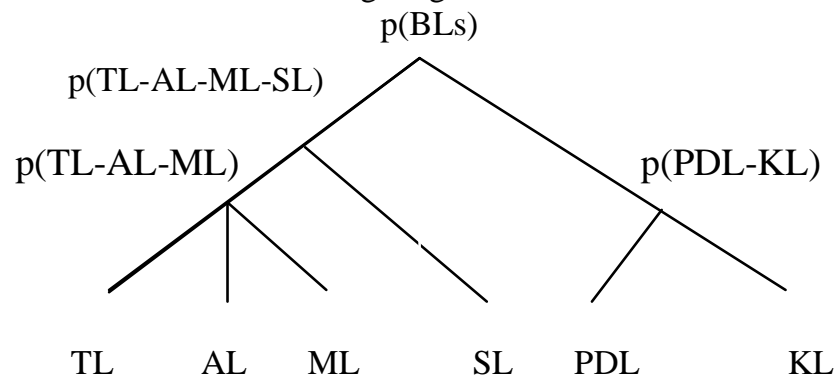

The diagram shows that TL-AL-ML has proto-nuclear, namely $\mathrm{p}$ (TL-AL-ML), TL-AL-ML along with SL has proto-nuclear, namely $\mathrm{p}$ (TL-AL-ML-SL), and PDL-KL has proto-nuclear, namely p(PDL-KL) before they are connected to proto-Batak Languages, $\mathrm{p}(\mathrm{BLs})$. 


\section{Conclusion}

According to the data analysis above, the sound correspondence sets with linear reflexes in BLs are as follows: $/ \Lambda-\Lambda-\Lambda-\Lambda-\Lambda-\Lambda /$ with proto-phoneme $/ *_{\Lambda} /, \quad / \mathrm{a}-\mathrm{a}-\mathrm{a}-\mathrm{a}-\mathrm{a}-\mathrm{a} /$ in initial, middle, and final positions with protophoneme $/ * \mathrm{a} /$, /u-u-u-u-u-u/ in initial, middle, and final positions with proto-phoneme /*u/, /i-i-i-i-i-i/ in initial, middle, and final positions with proto-phoneme $/ * \mathrm{i} /$, /b-b-b-b-b-b/ in intial and middle positions with protophoneme $/ * \mathrm{~b} /, / \mathrm{t}-\mathrm{t}-\mathrm{t}-\mathrm{t}-\mathrm{t}-\mathrm{t} / \mathrm{in}$ initial, middle and final positions with proto-phoneme $/ * \mathrm{t} /, / \mathrm{j}-\mathrm{j}-\mathrm{j}-\mathrm{j}-\mathrm{j}-\mathrm{j} /$ in initial and middle positions with proto-phoneme $/ * \mathrm{j} /$, /r-r-r-r-r-r/ in initial, middle, and final positions with proto-phoneme $/ * \mathrm{r} /, / 1-1-1-1-1-1 /$ in initial, middle, and final positions with proto-phoneme $/ * 1 /, / \eta-\eta-\eta-\eta-\eta-\eta-\eta /$ in initial, middle, and final positions with proto-phoneme /*n/, /p-p-p-p-p-p/ in initial, middle, and final positions with proto phoneme $/ * \mathrm{p} /$, /g-g-g-g-g-g/ in initial and middle positions with proto-phoneme /*g/, /d-d-d-d-d-d/ in initial and middle positions with proto-phoneme $/ * \mathrm{~d} /, / \mathrm{m}-\mathrm{m}-\mathrm{m}-\mathrm{m}-\mathrm{m}-\mathrm{m} /$ in initial, middle, and final positions with proto-phoneme $/ * \mathrm{~m} /$, , /s-s-s-s-s-s/ in initial, middle, and final positions with proto-phoneme $/ * \mathrm{~s} /$,and $/ \mathrm{n}-\mathrm{n}-\mathrm{n}-\mathrm{n}-\mathrm{n}-\mathrm{n} /$ in initial, middle, and final positions with proto-phoneme $/ * \mathrm{n} /$.

Meanwhile, the innovation-based sound correspondence sets in BLs are /0-0-e-o-e- $\mathrm{J} /$ in middle

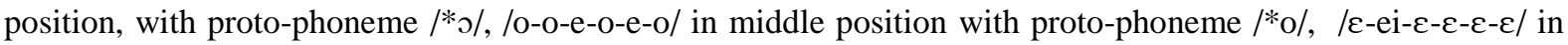
final position with proto-phoneme $/ * \varepsilon /, / \Lambda-\Lambda-\mathrm{a}-\Lambda-\mathrm{a}-\Lambda /$ in middle position with proto-phoneme $/ * \Lambda /$, /u-u-o-u-u-u/ in middle position with proto-phoneme $/ * \mathrm{u} / / / \mathrm{i}-\mathrm{i}-\mathrm{i}-\mathrm{i}-\mathrm{e}-\mathrm{i} /$ in middle position with proto-phoneme $/ * \mathrm{i} /, / \phi-\mathrm{h}-\mathrm{h}-\phi-\mathrm{h}-$ $\phi /$ in final position with proto-phoneme $/ * \mathrm{~h} /, / \phi-\phi-\mathrm{m}-\phi-\phi-\phi /$ in initial position with proto-phoneme $/ * \phi /, / \phi-\phi-\mathrm{n}-$ $\phi-\phi-\phi /$ in initial position with proto-phoneme $/ * \phi /, \quad / \phi-\phi-\eta-\phi-\phi-\phi /$ in initial position with proto-phoneme $/ * \phi /, / \mathrm{h}-$ $\mathrm{h}-\mathrm{k}-\mathrm{h}-\mathrm{k}-\mathrm{h} /$ in intial position with proto-phoneme $/ * \mathrm{k} /$, and /k-k-n-k-n-k/ in middle position with proto-phoneme $/ * \mathrm{n} /$.

BLs consist of three language sub-groups, namely TL-AL-ML, PDL-KL, and SL.

\section{References}

[1]. Brandstetter \& Dempwolf (1943). inWurm, S.A. \& Wilson, B. Pacific Linguistics. Series C- No.33. English Finderlist of Reconstructions in Austronesian Languages (Post- Brandstetter). (Canberra: Department of Linguistics Research School of Pacific Studies The Australian National University.1978)

[2]. Capell (1943).inWurm, S.A. \& Wilson, B.(Pacific Linguistics. Series C- No. 33. English Finderlist of Reconstructions in Austronesian Languages (Post- Brandstetter). (Canberra: Department of Linguistics Research School of Pacific Studies The Australian National University.1978)

[3]. Charles (1973).inWurm, S.A. \& Wilson, BPacific Linguistics. Series C- No. 33. English Finderlist of Reconstructions in Austronesian Languages (Post- Brandstetter). (Canberra: Department of Linguistics Research School of Pacific Studies The Australian National University.1978)

[4]. Crowley Terry. An Introduction to Historical Linguistics. (Oxford. Oxford University Press.1992)

[5]. Dempwolff (1938)inWurm, S.A. \& Wilson, B Pacific Linguistics. Series C- No. 33. English Finderlist of Reconstructions in Austronesian Languages (Post- Brandstetter). Canberra: Department of Linguistics Research School of Pacific Studies The Ustralian National University.1978)

[6]. Keraf, Gorys. Linguistik Bandingan Historis. (Jakarta: Gramedia Utama. 1991)

[7]. Langacker Ronald W.Fundamentals of Linguistics Analysis. (Sandiego: University of California. 1972)

[8]. Marice. Bahasa Batak Toba di Kota Medan (Kajian Interferensi dan Sikap Bahasa). (Medan: Sekolah Pascasarjana Universitas Sumatera Utara. 2010)

[9]. McManis, Carolyn, Stollenwerk \& Zheng-Sheng, Zhang.(Ohio: Language Files. Advocate Publishing Group.1987)

[10]. PanggabeanHimpun.Telaah Bahasa-bahasa Batak dari Segi Leksikostatistik. Bandung: Universitas Padjadjaran.1994)

[11]. Pike, Kenneth. L. Phonemics: A Techniquefir Reducing Language to Writing. (Michigan: 1968)

[12]. Sugono, Dendy et.al. Kamus Besar Bahasa Indonesia (Departemen Pendidikan Nasional, Jakarta:2008)

[13]. The Comparative Method and Linguistic Reconstruction, (Retrived on February 23, from http://en.wikipedia.org/wiki/Comparative_method)

[14]. Wurm, S.A. \& Wilson, B. Pacific Linguistics. Series C- No. 33. English Finderlist of Reconstructions in Austronesian Languages (Post- Brandstetter). Canberra: Department of Linguistics Research School of Pacific Studies The Australian National University. 1978) 